\title{
The impact of shipping emissions on air pollution in the greater North Sea region - Part 1: Current emissions and concentrations
}

\author{
A. Aulinger ${ }^{1}$, V. Matthias ${ }^{1}$, M. Zeretzke ${ }^{2}$, J. Bieser ${ }^{1}$, M. Quante ${ }^{1}$, and A. Backes ${ }^{1}$ \\ ${ }^{1}$ Helmholtz-Zentrum Geesthacht, Institute of Coastal Research, Max-Planck-Straße 1, 21502 Geesthacht, Germany \\ ${ }^{2}$ DNV-GL, Brooktorkai 18, 20457 Hamburg, Germany \\ Correspondence to: A. Aulinger (armin.aulinger@hzg.de)
}

Received: 29 January 2015 - Published in Atmos. Chem. Phys. Discuss.: 16 April 2015

Revised: 30 November 2015 - Accepted: 18 December 2015 - Published: 22 January 2016

\begin{abstract}
The North Sea is one of the areas with the highest ship traffic densities worldwide. At any time, about 3000 ships are sailing its waterways. Previous scientific publications have shown that ships contribute significantly to atmospheric concentrations of $\mathrm{NO}_{x}$, particulate matter and ozone. Especially in the case of particulate matter and ozone, this influence can even be seen in regions far away from the main shipping routes. In order to quantify the effects of North Sea shipping on air quality in its bordering states, it is essential to determine the emissions from shipping as accurately as possible. Within Interreg IVb project Clean North Sea Shipping (CNSS), a bottom-up approach was developed and used to thoroughly compile such an emission inventory for 2011 that served as the base year for the current emission situation. The innovative aspect of this approach was to use load-dependent functions to calculate emissions from the ships' current activities instead of averaged emission factors for the entire range of the engine loads. These functions were applied to ship activities that were derived from hourly records of Automatic Identification System signals together with a database containing the engine characteristics of the vessels that traveled the North Sea in 2011. The emission model yielded ship emissions among others of $\mathrm{NO}_{x}$ and $\mathrm{SO}_{2}$ at high temporal and spatial resolution that were subsequently used in a chemistry transport model in order to simulate the impact of the emissions on pollutant concentration levels. The total emissions of nitrogen reached $540 \mathrm{Gg}$ and those of sulfur oxides $123 \mathrm{Gg}$ within the North Sea - including the adjacent western part of the Baltic Sea until $5^{\circ} \mathrm{W}$. This was about twice as much of those of a medium-sized industrialized European state like the Netherlands. The relative contribution of ships to, for example, $\mathrm{NO}_{2}$ concentration levels ashore close to the
\end{abstract}

sea can reach up to $25 \%$ in summer and $15 \%$ in winter. Some hundred kilometers away from the sea, the contribution was about $6 \%$ in summer and $4 \%$ in winter. The relative contribution of the secondary pollutant $\mathrm{NO}_{3}^{-}$was found to reach $20 \%$ in summer and $6 \%$ in winter even far from the shore.

\section{Introduction}

Land-based sources of $\mathrm{SO}_{2}$ and $\mathrm{NO}_{x}$ have decreased substantially in Europe during the last 20 years, partly because of technical progress in the sectors of traffic, heating and industrial production, and partly because of the political and economic changes in eastern Europe since 1990. In contrast, measures to control ship emissions were disregarded for a long time. For a few years, however, the awareness of air pollution by shipping in particular concerning the emission of precursors for particulates has been rising (Eyring et al., 2005a, b; Lauer et al., 2009; Dentener et al., 2006), and political options to decrease ship emissions are being discussed. Ship traffic in the North Sea is now recognized by its adjacent states as a relevant source of air pollutants because future projections show that this traffic is likely to grow further during the coming decades (Project, 2014). For this reason, the North Sea was designated an Emission Control Area (ECA) with the objective of reducing the emissions of $\mathrm{NO}_{x}$ and $\mathrm{SO}_{2}$. Since November 2007 ships have been obliged to use fuel with a sulfur content not higher than $1.5 \%$. This limit was lowered to $1 \%$ in July 2010 and to $0.1 \%$ as of January 2015. In addition, from January 2010, the EU sulfur directive requires ships to use fuel with $0.1 \%$ or less in EU harbors. The introduction of a nitrogen control area in the 
North Sea was planned for 2016. However, this plan is suspended at the time of writing. In the second greenhouse gas study commissioned by the International Maritime Organisation (IMO), both the increase in ship traffic for the next 40 years and the implications of introducing ECAs on emission factors for $\mathrm{NO}_{x}$ and $\mathrm{SO}_{2}$ are described (Buhaug et al., 2009). Reducing emissions, however, does not necessarily allow one to draw conclusions about the actual concentration levels distant from the sources. This is even more true for secondary pollutants like particulate ammonium sulfate, ammonium nitrate or ozone that undergo chemical transformations while being transported in the atmosphere.

In this study, an emission inventory for ships in the North Sea for 2011 was created with a bottom-up modeling approach. The main purpose, however, was to use these emissions with a chemistry transport model (CTM) in order to quantify the effect of sea-going ships on air quality (with regard to $\mathrm{NO}_{2}, \mathrm{SO}_{2}$, ozone and $\mathrm{PM}$ ) in central and northern Europe. The year 2011 was supposed to be one of the first years of recovery after the world economic crisis at the end of the 2000s and, hence, representative of the current situation of the transport of goods.

Formerly, when little was known about ship activities and the emission behavior of their engines, the only way to estimate emissions of air pollutants from ships was to estimate fuel consumption by means of fuel sales numbers and multiply them by emission factors per units of fuel burned. This method is described in the CORINAIR guidelines (EEA, 2013), and it is partly used to date by the European member states in order to report national emissions to the European Union. It has, however, large uncertainties because the amount of fuel bunkered in northern Europe is not necessarily the same amount of fuel consumed there. Deriving emissions from combusted fuel is generally a suitable approach for sulfur dioxide and carbon dioxide emissions that depend only on the mass of fuel and the sulfur or carbon content in that fuel. However, the emissions of substances like $\mathrm{NO}_{x}, \mathrm{CO}$, hydrocarbons and particulate matter (PM) depend strongly on combustion temperature and the fuel to air ratio, which are related to the engine load.

With the introduction of the Automatic Identification System (AIS) for ships it became much easier to track ship movements and estimate their actual engine loads provided the necessary engine characteristics are known. When the Clean North Sea Shipping (CNSS) project started, emission factors were only available as constant values that had to be multiplied by the energy or fuel consumption of a ship (Denier van der Gon and Hulskotte, 2010; Matthias et al., 2010). One of the first studies about AIS-based ship emissions in the North Sea was published by MARIN (2011). The authors of that study calculated ship emissions of the year 2009 for the Netherlands Continental Shelf and extrapolated these emissions to the whole North Sea by means of ship traffic density maps from the Safety Assessment Model for Shipping and Offshore on the North Sea (SAMSON). Hammingh et al.
(2012) used the MARIN emission inventory for a study about the impact of introducing a Nitrogen Emission Control Area (NECA) on the environment and human health in the North Sea. In 2012, Jalkanen et al. (2012) published a study about a ship emission model (STEAM2) that followed an approach similar to the one presented here, also combining AIS signals with a ship characteristics database. On the one hand, the calculation of the instantaneous engine power is very elaborate in the STEAM2 model, using for example a ship resistance model, while the model presented here uses only the ratio between design speed and actual speed. On the other hand, the model presented here uses different emission factor functions for different engine types, vessel sizes and pollutants, while Jalkanen et al. (2012) derived load dependency of emission factors from only a few measured engines. Jonson et al. (2014) used results from the STEAM2 emission model for 2011 to estimate the contribution of ships to pollutant concentrations and depositions over Europe, and Johansson et al. (2013) extended STEAM2 for a study of the evolution of shipping emissions in northern Europe. Another study about the contribution of ships to air pollution that also investigated health effects and external costs was published by Brandt et al. (2013). It may be valuable to compare the different models and their results in detail, which is, however, beyond the scope of this study. Instead, the plausibility of the ship emissions presented here and their contribution to air pollution were evaluated by performing statistical tests with observed concentrations available from the European Monitoring and Evaluation Programme (EMEP) network (EMEP, 2015).

\section{Ship-emissions model}

First of all, the bottom-up approach we followed to estimate ship emissions for the year 2011 required activity data about the ships traveling the North Sea. As one of the most effective ways to derive ship activities, the evaluation of signals from the Automatic Identification System (AIS) was established in recent times (Jalkanen et al., 2012). In order to avoid collisions, all ships bigger than 100 gross tons (GT) are obliged to broadcast such a signal every $6 \mathrm{~s}$ to indicate - amongst others - their identification number, position, moving status, direction and speed over ground. Some enterprises like IHS Fairplay store these signals for further evaluation and make them available for purchase. On the basis of AIS data, it is possible to follow the route of a single ship and to estimate its energy demand, fuel consumption and pollutant exhaust along this route.

The second requirement for a bottom-up inventory are activity-based emission factors for different ship types. Such a set of emission factors in the form of load-dependent functions resulted from a study of Germanischer Lloyd (GL) (Zeretzke, 2013) within Inrerreg IVb project Clean North Sea Shipping (CNSS). The engine characteristics needed to 


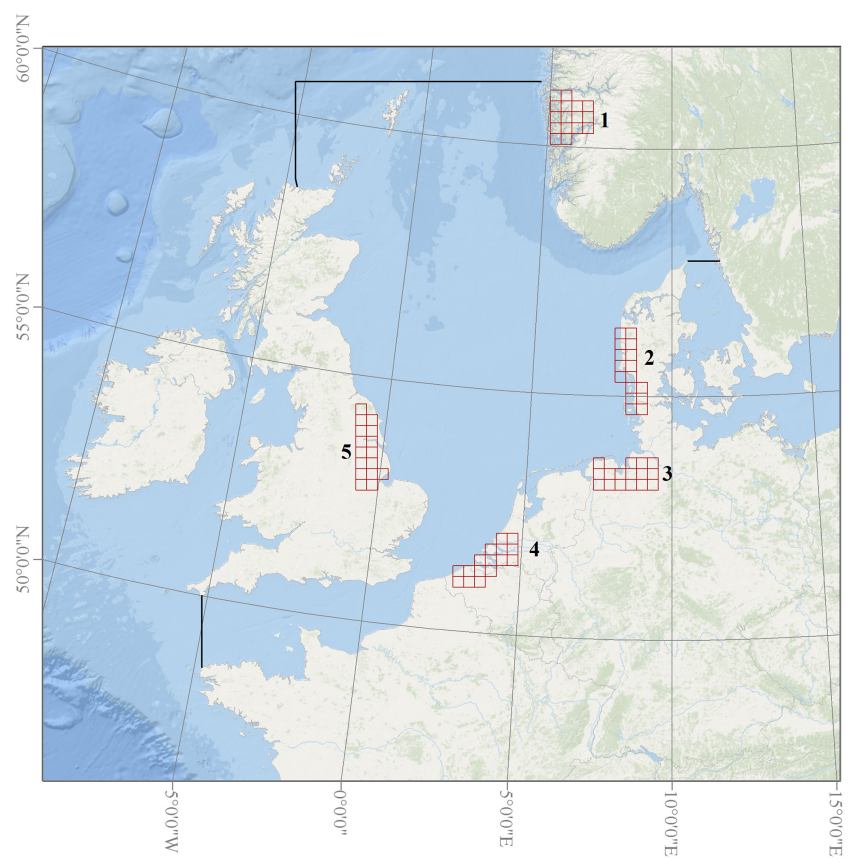

Figure 1. Modeling domain with the borders of the OSPAR region II and the cells that were defined as representative coastal areas.

calculate the engine loads were taken from a database acquired from IHS Fairplay combined with one from GL. The model approach developed in this study uses these functions together with interpolation routines, which allows for simulation of ship emissions at nearly arbitrary temporal and spatial resolution. In order to use the ship emissions in a chemistry transport model (CTM), they had to be transferred from latitude-longitude positions to a regularly spaced Eulerian grid.

\subsection{Ship routes derived from AIS data}

The AIS database that was acquired from IHS Fairplay contains hourly updated AIS data in the OSPAR region II, defined within the Convention for the Protection of the marine Environment of the North-East Atlantic (the OSPAR Convention) for the whole year 2011 (Fig. 1). According to these data, about 3000 ships with a valid IMO number were active in the North Sea on average per hour in 2011. However, the spatial density of the hourly signals appeared to be too sparse for creating gridded emissions at a resolution required by the used chemistry transport model setup. In addition to this, the coverage of received AIS signals is low in some regions, especially on the open sea. Therefore, the broadcast positions along a ship track were interpolated linearly to complete tracks and to get enough points for transferring the track to the Eulerian grid. Several routes were predefined that ships would use to circumnavigate certain capes or coastlines. In case an interpolated track point was positioned on land, it was moved to the appropriate predefined route. The

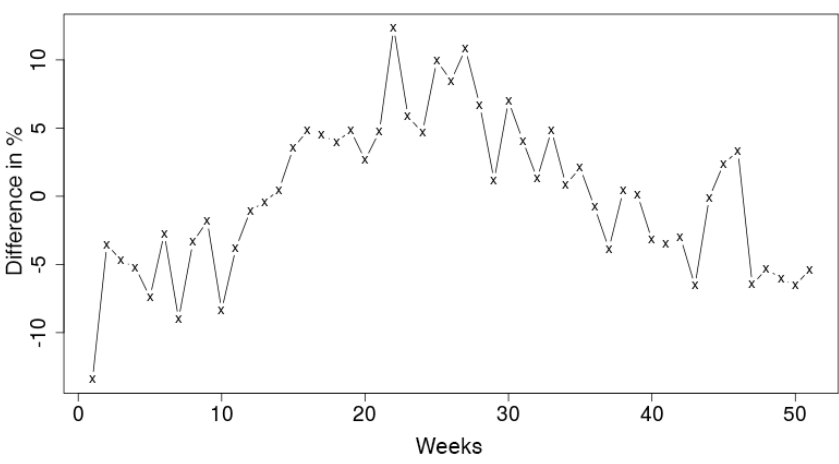

Figure 2. Monthly deviation from the annual mean fuel consumption in the North Sea in \%.

vessel whose track was to be reconstructed was identified by its International Maritime Organisation (IMO) or Maritime Mobile Service Identity (MMSI) number contained in the AIS data.

In order to elaborate a temporal emission profile of the ship activities - and hence emissions - the ship emissions for 2011 were calculated as 52 weekly sums (Fig. 2). Using weekly and not daily or hourly data reflects the necessity of having enough points to reconstruct and complete ship tracks. The procedural steps were as follows.

1. Read data sets from the AIS database of 1 week.

2. Subset the weekly AIS data by one vessel (IMO or MMSI number).

3. Sort by time stamp: this yields the track of one ship in 1 week sailing the North Sea.

4. Interpolate the ship track so that it consists of equidistant points. The distance between the track points is set to $1 / 3$ of the length of a grid cell. Make sure the track does not lead over land.

5. Calculate speed at every track point.

\subsection{Handling erroneous records in the AIS data}

\subsubsection{Implausible ship movements}

AIS signals that contained a requested IMO number but did obviously not belong to the current track resulted in an unrealistic movement of the ship. For example: a ship could jump from the German coast to Norway and back. These signals and the track points contained therein were detected in case the calculated speed between two track points was $20 \%$ higher than the maximum of all reported speeds in the AIS signals of this track. The second one of these points was then removed from the track and the track was recalculated with the remaining points. If there was more than one implausible point in the track, they were removed recursively. The assumption was that the preceding points in the track reflected 
correct AIS signals. The pitfall is, of course, that the correct points could have been removed and erroneous ones kept. Following this procedure, about $2 \%$ of the track points found through AIS signals had to be dismissed. Because of the subsequent interpolation, however, this should have a negligible influence on the reconstruction of the ship tracks.

\subsubsection{Mooring ships with unknown demooring point of time}

In some cases the AIS signal of a ship disappeared for some time while the ship was mooring and did not reappear immediately after it had demoored. Then, the calculated voyage time between the mooring place $M$ and the next captured AIS position $T$ was too long and the calculated speed was too low (the threshold is $40 \%$ of speed over ground at position $T$ ). When this was detected the speed over ground at position $T \operatorname{sog}(T)$ was assumed for the whole journey between $M$ and $T$. In that case, the demooring point of time $\operatorname{clock}(M)$ was calculated with the formula below. This approach did not consider that it takes some time until a vessel reaches its cruising speed. The same procedure was applied to correct low speeds in the case where a ship leaves the domain and returns many hours later.

$\operatorname{clock}(M)=\operatorname{clock}(T)-\frac{\operatorname{distance}[M T]}{\operatorname{sog}(T)}$

\subsection{Attribute ship characteristics to track}

Ships in the AIS database were usually identified by their unique IMO number. In some cases where the IMO number of a record in the database was missing or invalid, vessels were identified by the MMSI number of their broadcasting devices. In cases where the same IMO number corresponded to more than one MMSI number, the most frequently found pair was chosen to identify the IMO number of a vessel.

By means of the IMO number of the vessel - whose weekly track was reconstructed as explained above - the technical characteristics needed to calculate the emissions of that track were selected from a ship characteristics database that was also acquired from IHS Fairplay or in a second one provided by GL. If the IMO number was present in both databases and the values were contradictory, the values of the IHS database were used.

All vessels in the database were divided into seven types (tankers, bulk ships, cargo ships, cruise ships, ferries, tugs and other vessels) and nine size classes defined by gross tonnage (GT). In several cases single characteristics were missing for a ship. To account for these gaps, a look-up table was compiled containing median values per ship class and type whose values were used if not found in the database. For nonnumeric characteristics like fuel type, the most frequent one was taken. If no median could be calculated for a particular class, the median of a neighboring class was taken (see Appendix A1).

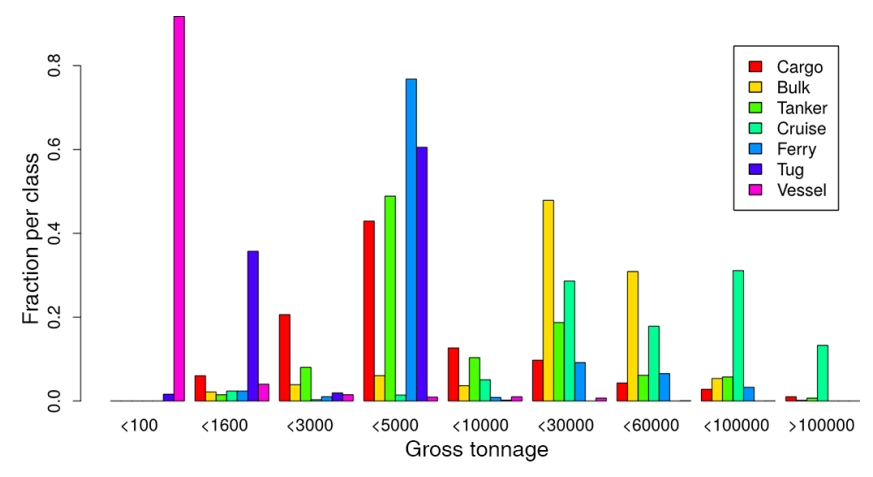

Figure 3. Distribution of ship types across classes.

These medians are used to complete missing data if feasible as follows.

- The GT and type of that ship was found: use class medians for missing characteristics.

- IMO is valid but not found in databases; AIS contains a valid ship type: use medians of the peak of the frequency distribution for this ship type (Fig. 3).

\subsection{Emission factors}

In the ship emission model presented here, methods for calculating fuel consumption and pollutant emissions developed at Germanischer Lloyd (GL) (Zeretzke, 2013) were implemented. For fuel consumption and, hence, $\mathrm{SO}_{2}$ emissions and $\mathrm{NO}_{x}$ emissions, these methods consist of functions to calculate load-dependent factors in $\mathrm{g}(\mathrm{kWh})^{-1}$. Specific functions were developed for different engine applications, namely E3 (propeller-law-operated main and propeller-lawoperated auxiliary engine application), E2 (constant-speed main propulsion application including diesel-electric drive or variable-pitch propeller installations) and D2 (constantspeed auxiliary engine application) as well as different engine sizes defined by their maximum continuous rating in $\mathrm{kW}$ (MCR). For some of the particulate pollutants, namely black carbon, secondary organic aerosols and mineral ash where no functional relationships could be found, constant emission factors for all engine loads were used. The emission factors and functions were found by evaluating a database of 446 test bed measurements. The resulting formulas and emission factors are summarized in Appendix A.

\subsection{1 $\mathrm{SO}_{2}$}

The $\mathrm{SO}_{2}$ emissions are directly dependent on the fuel consumption and the sulfur content of the fuel. The fuel consumption was calculated using the appropriate functions differentiating between engine type and size (Appendix A) and the energy consumption as described in Sect. 2.5. The sulfur fuel content is dependent on the type of fuel used, which 
Table 1. Ratio of $\mathrm{NO}_{x}$ emissions per size class and ships built between 1990 and 2000 (retrofit) and the share of these ships in total $\mathrm{NO}_{x}$ emissions in \%.

\begin{tabular}{rlrrr}
\hline & Class & $\mathrm{NO}_{x}$ & Retrofit & $\mathrm{NO}_{x}$ share \\
\hline 5 & $<10000$ & 7.8 & 23.8 & 1.9 \\
6 & $<30000$ & 24.5 & 24.5 & 6 \\
7 & $<60000$ & 18.7 & 26.5 & 5 \\
8 & $<100000$ & 21.1 & 1.8 & 0.4 \\
9 & $\geq 100000$ & 7.3 & 0 & 0 \\
\hline
\end{tabular}

is unfortunately unknown for most of the ships in our vessel database. Therefore, we decided to use the speed of the engines to determine the fuel used. Zeretzke (2013) assumes that $95 \%$ of the engines running at between 60 and $300 \mathrm{rpm}$ use heavy fuel oil (HFO), while only $70 \%$ of the engines running at between 300 and $1500 \mathrm{rpm}$ use HFO. The remaining vessels only use marine diesel oil (MDO). According to the MARPOL regulations in 2011 (IMO, 2008), the sulfur fuel content of the vessels while moving in the North Sea ECA was set to $1 \%$ for ships running on $\mathrm{HFO}$ and $0.2 \%$ for ships using MDO. If ships using HFO were sailing outside the ECA, the average sulfur content of the HFO allowed in international shipping of $2.7 \%$ was used.

\subsection{2 $\mathrm{NO}_{x}$}

Because the emissions of $\mathrm{NO}_{x}$ are not linearly related to the fuel consumption, Zeretzke (2013) developed a separate set of functions to calculate load-dependent emission factors for $\mathrm{NO}_{x}$. These functions differ not only by engine type and size, but also consider the year of build because vessels built after 2000 had to comply with TIER I regulations, while ships built after 2011 complied with TIER II. The test bed measurements revealed that the emissions of vessels having TIER I specifications were $23 \%$ lower than the officially allowed TIER I value. Therefore, the emission factor for ships built before 2000 was determined by calculating the factor with the formula for the TIER I regulation and multiplying this by 1.6 , which considers also the recommendations of Mollenhauer and Tschöke (2007), who estimate that preTIER engines emit on average $30 \%$ more $\mathrm{NO}_{x}$ than TIER I engines. The test bed measurements were carried out with MDO, which has a very low nitrogen content. This means that the formulas for calculating the $\mathrm{NO}_{x}$ emission factors consider only $\mathrm{NO}_{x}$ from atmospheric $\mathrm{N}_{2}$. Because, according to Zeretzke (2013), the nitrogen content of HFO of up to $0.6 \%$ should not be neglected, our model considers $\mathrm{NO}_{x}$ emissions of $5.6 \mathrm{~g} \mathrm{~kg}^{-1} \mathrm{HFO}$ burned.

In addition to new ships, built after 2000, TIER I standards also become applicable to existing engines that were installed on ships built between 1 January 1990 and 31 December 1999, with a displacement of at least $90 \mathrm{~L}$ per cylinder and rated output of at least $5000 \mathrm{~kW}$, subject to availabil-
Table 2. Emission factors for $\mathrm{BC}, \mathrm{POA}$ and mineral ash in $\mathrm{g}(\mathrm{kWh})^{-1}$.

\begin{tabular}{lcrrr}
\hline Application & Fuel & E3 & E2 & D2 \\
\hline BC & HFO & 0.06 & 0.06 & 0.15 \\
& MDO & 0.03 & 0.03 & 0.15 \\
POA & & 0.1 & 0.1 & 0.15 \\
Mineral ash & HFO & 0.1 & 0.1 & 0.1 \\
& MDO & 0.01 & 0.01 & 0.01 \\
\hline
\end{tabular}

ity of an approved engine upgrade kit (IMO, 2008). However, we did not consider this because there was no information in the engine database on whether an engine complied with TIER I, and we did not find any information about how many ships built in the nineties were actually retrofitted. To assess the error this negligence would introduce into the model, we counted the number of vessels in each class built between 1990 and 2000. Weighting the percental $\mathrm{NO}_{x}$ emissions with the relative number of potentially retrofitted vessels per class reveals that $13 \%$ of the $\mathrm{NO}_{x}$ emissions was caused by vessels built between 1990 and 2000 that had a MCR of more than $5000 \mathrm{~kW}$ (Table 1). Considering the pre-TIER factor of 1.6 means that the overestimation of $\mathrm{NO}_{x}$ emissions was $8 \%$ at maximum. Assuming further that for half of these vessels upgrade kits were available, we estimate the overestimation in $\mathrm{NO}_{x}$ emissions at $4 \%$.

\subsubsection{Particulates}

The particle emissions that were measured at GL included sulfuric acid and sulfate, mineral ash, black carbon (BC) and primary organic aerosols (POA). Unlike directly on load, the emission factors for particulate species depend on the type of fuel and fuel consumption - hence, indirectly on the engine load. The emissions of particulate sulfate were calculated in the model assuming that $5 \%$ of the sulfur in the fuel is emitted as sulfuric acid. The CMAQ chemistry transport model does not distinguish between sulfate and sulfuric acid, but treats both as sulfate aerosol.

Both BC and POA were analyzed by a sequential thermal carbon analyzer separating organic from non-organic carbon, which ensured a minimum overlap between BC and POA (VDI, 1996, 1999). Because of the dependency of BC emissions on the sulfur content in fuels (Kurok, 2008; Lack and Corbett, 2012), there are different emission factors for MDO and HFO. The emission factors proposed for the non-carbon ash fraction assume that this ash consists of metal oxides; it does not take into account that some metals form metal sulfates. As the percentage of sulfates in this mineral ash is unknown and the mineral ash fraction is small, we decided to use these emission factors without any sulfate correction (Table 2). 


\subsection{Emission calculation}

Energy consumption, fuel consumption and the emissions of $\mathrm{NO}_{x}, \mathrm{SO}_{2}$, mineral ash, sulfuric acid, $\mathrm{BC}$ and POA were calculated for every track point where the calculated speed was larger than $2 \mathrm{kn}$. This $2 \mathrm{kn}$ was assumed to be the threshold, indicating that the ship was neither mooring nor maneuvering. This means, of course, that the emissions of ships in ports are underestimated. According to Hammingh et al. (2012), port emissions account for ca. $10 \%$ of the $\mathrm{NO}_{x}$ emissions in the North Sea, half of which is emitted from ships at berth. Extrapolating the $\mathrm{NO}_{x}$ emissions of 2011 in the port of Antwerp, which was estimated for the CNSS project, to the five biggest North Sea ports suggested an underestimation of $6.4 \%$. Because ports cover only a small part of the entire area of the applied regional model, we considered this lack to be acceptable. In future versions the inclusion of a port emissions model is planned.

Consumption and emissions depend on the actual load $L$ of the ship that was calculated with the speed at MCR and the calculated actual speed (scalc). Calculating the energy consumption $E$ was then straightforward using MCR, the actual load and the time difference between two track points $\Delta t$.

$\begin{aligned} L & =\left(\frac{\text { speed }_{\mathrm{MCR}}}{\text { scalc }^{3}}\right)^{3} \\ E & =L \times \mathrm{MCR} \times \Delta t\end{aligned}$

For auxiliary engines the load for moving ships was kept constant at 0.3 following a suggestion by Whall et al. (2002). In a sensitivity model run we increased the auxiliary engine load to 0.4 and found that this would increase the total fuel consumption on the North Sea by $4 \%$. Fuel consumption and pollutant emissions Em were calculated by multiplying the energy consumption $E$ by specific emission factors $E F$ in $\mathrm{g}(\mathrm{kWh})^{-1}$ (Appendix Sects. A2 and A3). These emission factors are a function of load $L$, propulsion type $P$ (applications E2, E3, D2), fuel type $F$ (heavy fuel oil or marine diesel oil) and year of build $Y$.

$$
\begin{aligned}
& \mathrm{EF}=f(L, P, F, Y) \\
& \mathrm{Em}=\mathrm{EF} \times E
\end{aligned}
$$

The load was kept between 1 and 0.25 because the emission factors are only applicable for this range according to Zeretzke (2013). If the design speed of a ship $\left(\operatorname{speed}_{\mathrm{MCR}}\right)$ was lower than the maximum reported speed over ground (sog) along the track - corrected for implausible track points - speed $_{\text {MCR }}$ was set to $\max (\operatorname{sog})$. However, the actual speed and engine load of a vessel are influenced by external effects like currents and wind. Applying this artificially increased design speed could, however, also lead to underestimations of the vessel's engine load in cases where the assumed conditions do not apply or if the real conditions decrease the maximum speed - for example if the vessel moves against the current. Through a sensitivity run we estimated for vessels of class 6 (which have the largest share in fuel consumption) a worst case underestimation of ca. $9 \%$. On the other hand, external effects can also lead to overestimations, so that the underestimations for the entire year on the whole North Sea may be far below $9 \%$. The most appropriate way to deal with external effects would be to take them directly into account provided these effects were known. This would require, however, a lot of data (for example, about the ship's hull, draught, fouling, wind, currents, wave height) that were not available. In our opinion, estimating all these variables would introduce many hardly quantifiable uncertainties.

Loads lower than 0.25 were set to 0.25 . An exception was the calculation of $\mathrm{BC}$ emissions because it is known that these increase significantly at low loads. We used the formulas below to calculate a correction factor for $\mathrm{BC}$ emissions $f_{\mathrm{BC}}$. They were derived as a piece-wise linear fit to an average relation between engine load and $\mathrm{BC}$ emissions shown in a diagram by Lack and Corbett (2012).

$$
\begin{array}{rr}
f_{\mathrm{BC}}=\frac{6-0.12 \times L}{1.2} & 0<L \leq 0.25 \\
f_{\mathrm{BC}}=\frac{3-0.052 \times(L-0.25)}{1.2} & 0.25<L \leq 0.50 \\
f_{\mathrm{BC}}=\frac{1.7-0.02 \times(L-0.50)}{1.2} & 0.50<L \leq 0.75 \\
f_{\mathrm{BC}}=\frac{1.2-0.008 \times(L-0.75)}{1.2} & 0.75<L \leq 1
\end{array}
$$

\subsection{Transferring the line sources to the model grid}

The last step was to transfer these line source emissions to the grid cells of the model domain. The model domain consists of equally spaced grid cells in a Lambert conformal projection. Therefore, the track points defined by latitudelongitude coordinates were converted to Lambert $x-y$ coordinates. Next, the grid cells in which the track points lie were found and all emissions in a cell summed up and added to the domain.

\section{Ship emission inventory}

Most of all, the exhaust of pollutants is connected with the fuel consumption and, thus, with the energy demand of the ships. Therefore, the sections of the North Sea where the highest emissions of pollutants occurred were those where the majority of the big ships with high energy demand sail. These are the English Channel and the route along the North Sea coast between Belgium and Germany because the largest ships head for the three biggest ports in Europe, Rotterdam, Antwerp and Hamburg. From there, goods are distributed to smaller ports with medium-sized ships that account for regional and inner-European shipping. The main routes for medium-sized ships extend between central-western Europe and Scandinavia. It is a fundamental plausibility check for 


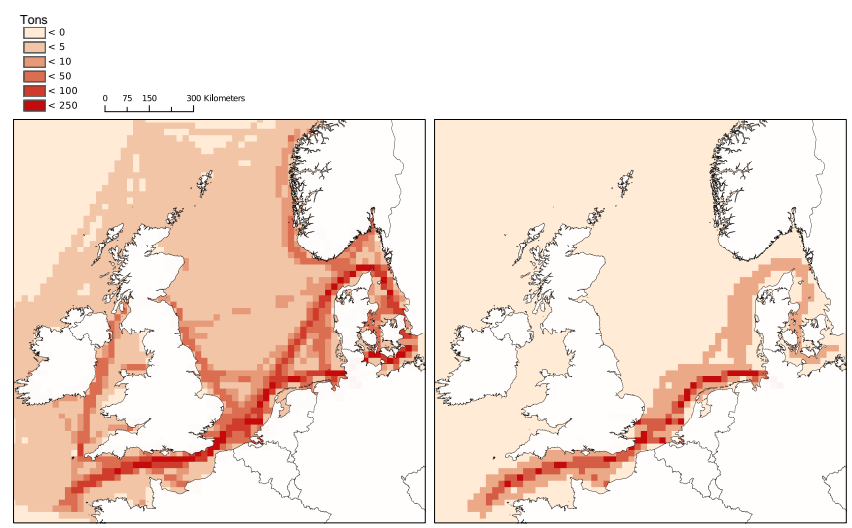

Figure 4. $\mathrm{NO}_{x}$ emissions of cargo ships between 5000 and 10000 GT (left) and > $100000 \mathrm{GT}$ (right).

the bottom-up emission approach that these main shipping lanes could be reconstructed from the AIS database (Fig. 4). Thus, the emissions of smaller ships were spread all over the North Sea, while the large vessels that only sail certain routes along the coasts were responsible for the peak values there.

Table 3 shows the percentage of ships of different sizes concerning total fuel consumption, $\mathrm{NO}_{x}$ and $\mathrm{SO}_{2}$ emissions on the North Sea. It also quantifies the differences normalized by the number of ships per size class - representing differences between average ships of the size classes - and the differences normalized by the transport volume per size class. It is evident that the share of air pollution of the large ships was big if single ships were compared, but small if it was related to the freight volume of the ships. This suggests that using large vessels to transport large amount of goods causes fewer emissions than using smaller vessels for the same amount of goods, provided, of course, that the large vessels use their full freight capacity. In this comparison, however, it should be kept in mind that the amount of goods distributed by medium-sized ships to smaller ports in the North and Baltic seas depends on the freight shipped with large vessels from all over the world. The total calculated ship emissions in 2011 in the study area were lower than those of the big industrial countries like Germany, the UK and France, but higher than those of smaller countries (Fig. 5).

A closer look at Table 3 reveals that the relations are not exactly the same for all pollutants. The exhaust of sulfuric acid and $\mathrm{SO}_{2}$ depends both on the fuel consumption and on the sulfur contents of the fuels used. On the one hand, the specific fuel consumption in $\mathrm{g}(\mathrm{kWh})^{-1}$ of smaller ships is higher than that of bigger ones. On the other hand, $95 \%$ of the large ships use high sulfur fuel (1.0\% $\mathrm{S}$ within SECA), in contrast to $75 \%$ of the medium-sized ships, so that it could be expected that the share of sulfur emissions for larger ships was higher even if the share in fuel consumption was lower. This relation should be reversed for $\mathrm{NO}_{x}$ exhaust because the

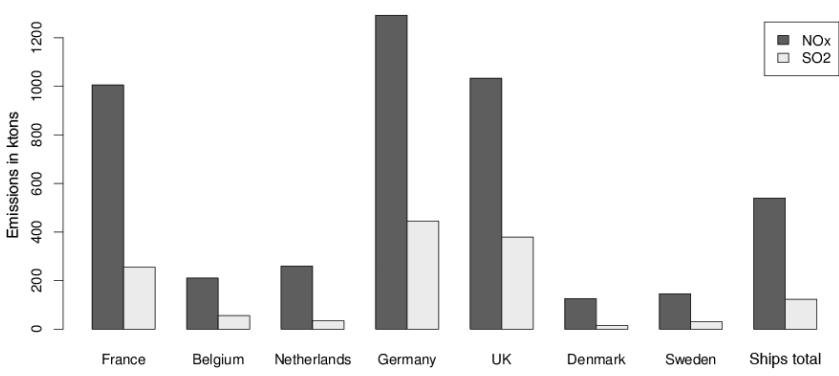

Figure 5. Total $\mathrm{NO}_{x}$ and $\mathrm{SO}_{2}$ emissions of ships in 2011 compared to some country emissions.

combustion temperature in smaller engines is higher, which promotes the creation of oxidized nitrogen (Zeretzke, 2013). In our data set of 2011, this effect appeared to be only weakly pronounced. Ships larger than $60000 \mathrm{GT}$ consumed $83.1 \%$ of the fuel while causing $83.6 \%$ of $\mathrm{SO}_{2}$ and $82.7 \%$ of the $\mathrm{NO}_{x}$ emissions, whereas smaller ships consumed $16.9 \%$ of the fuel and caused $16.4 \%$ of the $\mathrm{SO}_{2}$ and $17.3 \%$ of the $\mathrm{NO}_{x}$ emissions (Table 3).

The total ship emissions in 2011 for the model area, which covers the North Sea and the adjacent western part of the Baltic Sea (untit $5^{\circ} \mathrm{W}$ ), amounted to $540 \mathrm{Gg}$ for $\mathrm{NO}_{x}$ and $123 \mathrm{Gg}$ for $\mathrm{SO}_{2}$. At the same time, the officially reported emissions for the North Sea were $798 \mathrm{Gg}$ for $\mathrm{NO}_{x}$ and $192 \mathrm{Gg}$ for $\mathrm{SO}_{2}$ (EMEP/CEIP, 2014). Even if the areas are not the same, the differences seem to be remarkable. Recent investigations by Vinken et al. (2014) using satellite data suggested that the officially reported ship emissions might be overestimated by about $35 \%$. In 2015, EMEP revised the emissions provided through their website to $644 \mathrm{Gg}$ for $\mathrm{NO}_{x}$ and $162 \mathrm{Gg}$ for $\mathrm{SO}_{2}$ (EMEP/CEIP, 2015). The reason for the revision is, however, not explained. Table 4 illustrates the variation of ship emission estimates by different models. A further discussion of these differences would require one to investigate the differences of the methods applied to create the inventories, which is not intended in this paper.

\section{Model setup for the chemistry-transport simulations}

The contribution of shipping to air quality in the North Sea area can be determined by combining accurate emission inventories with advanced three-dimensional chemistry transport (CTM) models. A CTM imports emissions and uses meteorological data like wind speed, wind direction, radiation and temperature to simulate transport and chemical transformation of pollutants in the atmosphere. In this way, the CTM developed by the US Environmental Protection Agency, called the Community Multi-scale Air Quality (CMAQ) model, was used to calculate air concentrations of a number of pollutants depending on the input emissions. 
Table 3. Percentage of different ship sizes in fuel consumption and emissions within the model domain in 2011; middle: normalized by the number of ships in every class; right: normalized by the transported freight volume in every class (estimated from the gross tonnage).

\begin{tabular}{lrrrrrrr|rrr}
\hline & & & \multicolumn{9}{c}{ Normalized by counts } & \multicolumn{3}{|c}{ Normalized by freight } \\
Class & $\mathrm{GT}$ & Fuel & $\mathrm{SO}_{2}$ & $\mathrm{NO}_{x}$ & Fuel & $\mathrm{SO}_{2}$ & $\mathrm{NO}_{x}$ & Fuel & $\mathrm{SO}_{2}$ & $\mathrm{NO}_{x}$ \\
\hline 2 & $<1600$ & 1.6 & 1.6 & 1.4 & 0.9 & 0.9 & 0.8 & 34.1 & 33.9 & 31.9 \\
3 & $<3000$ & 1.7 & 1.7 & 1.6 & 0.6 & 0.6 & 0.5 & 5.6 & 5.6 & 4.9 \\
4 & $<5000$ & 16.8 & 16.8 & 17.6 & 2.6 & 2.6 & 2.7 & 14.9 & 14.7 & 16.2 \\
5 & $<10000$ & 7.9 & 7.9 & 7.8 & 3.7 & 3.8 & 3.6 & 12.1 & 12.3 & 12.3 \\
6 & $<30000$ & 25.1 & 25.4 & 24.5 & 9.1 & 9.4 & 8.8 & 10.4 & 10.7 & 10.6 \\
7 & $<60000$ & 18.7 & 18.8 & 18.7 & 14.9 & 15.2 & 14.8 & 8.4 & 8.5 & 8.8 \\
8 & $<100000$ & 21.3 & 21 & 21.1 & 28.6 & 28.6 & 28 & 8.2 & 8.1 & 8.4 \\
9 & $\geq 100000$ & 7 & 6.8 & 7.3 & 39.6 & 39 & 40.8 & 6.4 & 6.2 & 6.9 \\
\hline
\end{tabular}

Table 4. Comparison of ship emissions in the North Sea in Gigagrams estimated in different studies.

\begin{tabular}{lccl}
\hline Study & $\mathrm{NO}_{x}$ & $\mathrm{SO}_{2}$ & Remarks \\
\hline EMEP & 789 & 192 & $\begin{array}{l}\text { Emissions 2011, designated ECA zone excluding ports (EMEP/CEIP, } \\
\text { 2014) }\end{array}$ \\
\hline EMEP & 644 & 162 & $\begin{array}{l}\text { Emissions 2011, designated ECA zone excluding ports, revised in 2015 } \\
\text { (EMEP/CEIP, 2015) }\end{array}$ \\
\hline MARIN & 472 & 177 & Emissions 2009, designated ECA zone including ports (MARIN, 2011) \\
\hline Johansson & 648 & 151 & $\begin{array}{l}\text { Emissions 2011, designated ECA zone including ports (Johansson et al., } \\
2013)\end{array}$ \\
\hline This study & 540 & 123 & $\begin{array}{l}\text { Emissions 2011, designated ECA zone, area between } 5^{\circ} \mathrm{W} \text { and } 12^{\circ} \mathrm{E} \\
\text { excluding ports }\end{array}$ \\
\hline
\end{tabular}

The CMAQ model was used in its version 4.7.1 with the CB05 chemistry mechanism (Byun and Ching, 1999; Byun and Schere, 2006). It was run on a $24 \times 24 \mathrm{~km}^{2}$ Lambert conformal grid for an entire year with a spin-up time of 2 weeks and a data output time step of $1 \mathrm{~h}$. The model uses 30 vertical layers reaching approximately $10000 \mathrm{~m}$ at the top, the lowest two layers having a height of $36 \mathrm{~m}$. Boundary conditions for the model were from the TM5 global chemistry transport model system (Huijnen et al., 2010). The meteorological fields that drive the chemistry transport model were produced with the COSMO-CLM mesoscale meteorological model for the year 2008 (Rockel et al., 2008). This year was chosen because it did not include very unusual meteorological conditions in central Europe and can therefore be considered to represent average weather conditions in Europe. The simulation of atmospheric chemical processes is of particular importance for estimating concentrations of secondary pollutants that are not emitted directly but formed from emitted gases by chemical reaction. The most prominent one is ozone, whose formation is influenced by $\mathrm{NO}_{x}$. Also very important for health and environment is secondary particulate matter that emerges from gaseous emissions, mostly $\mathrm{NO}_{x}$ and $\mathrm{SO}_{2}$, and constitutes the largest portion of the noxious fine particulate matter. Emissions from other sources like traffic, industry, households and agriculture as well as shipping emissions from outside the domain of the ship emissions model were taken from official European emission inventories (EMEP/CEIP, 2014) and made model ready with the Sparse Matrix Operator Kernel Emissions model for Europe (SMOKE-EU; Bieser et al., 2011). Model runs were performed both using all available emissions including the ship emission inventory and using land-based emissions exclusively. The resulting concentration differences between these runs revealed the impact of shipping emissions.

\section{Simulation results}

\subsection{Validation of simulations through comparison to observations}

Several air pollutants are routinely measured by European authorities. The measurement data are available for download via the EMEP internet sites (EMEP, 2015) and can be used to validate model results. Even if it must be taken into account that the location where the measurement takes place may not be fully representative of the model grid cell this location belongs to and the overall measurement uncertainty of the observations is not known, this comparison provides 


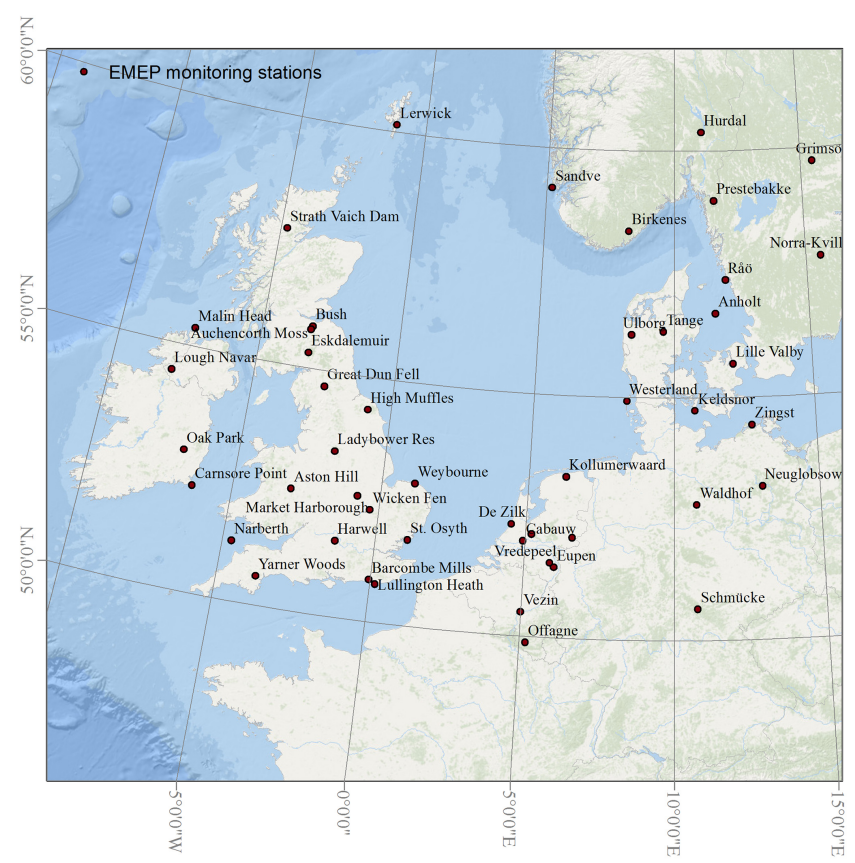

Figure 6. Locations of the EMEP measurement stations used for model evaluation.

a good indication of the plausibility of the simulated concentrations. The comparison involves both a graphical comparison of concentration time series and the calculation of some statistical parameters. The authors decided to use only those stations for model evaluation at which values were provided on more than 200 days.

The agreement between measurements and simulations is different at different measurement stations. Very low background concentrations are usually both difficult to measure and to predict correctly with models. To assess the agreement between observations and simulations, the correlation coefficient and the normalized mean bias (NMB) were used (Tables 5 through 7). With only a few exceptions, both the measured and modeled concentrations were found to be not normal but logarithmically distributed. In these cases, the mean values shown are geometric means and the correlation was calculated as Spearman rank correlation. Only the NMB was calculated from original concentration values because the authors regarded it as a non-parametric estimator.

Without knowing the measurement conditions and the observation site it is hardly possible to explain the differences exactly. Nonetheless, some cautious but plausible conclusions can be drawn.

\subsubsection{Assessment of the base case model results}

Because observations of $\mathrm{NO}_{2}$ are usually available as daily averages, the hourly model output was also recalculated to daily mean values. The resulting time series were compared to the daily mean of observations at measurement stations in
North Sea bordering states (Fig. 6). As often seen with air quality models, CMAQ tended to predict lower $\mathrm{NO}_{2}$ concentrations than measurements would suggest (Bessagnet et al., 2014), which can be seen in the negative NMB. If the time profile of the predicted values resembles that of the observations and if peak values in the measurements are met by the predictions, a correlation should be found. Without testing the significance of the correlation explicitly, we consider a correlation coefficient of more than 0.5 to indicate a correlation, whereas we speak of a good correlation at values of 0.7 and above. Concerning $\mathrm{NO}_{2}, 17$ out of 29 stations had a correlation coefficient of at least 0.7 , whereas only three showed a coefficient below 0.5 (Table 5). Stations with low correlation are those that lie in a difficult heterogeneous terrain like rocky coastal areas or on a small island in the sea, or where the background concentrations are very low with no peaks but only random variations of the signal.

$\mathrm{SO}_{2}$ concentrations are generally lower than $\mathrm{NO}_{2}$ concentrations. This may be a reason for the correlation coefficients being lower than for $\mathrm{NO}_{2}$. None of the 15 available stations showed a correlation coefficient higher than 0.7 (Table 6). At least seven of them had a value of more than 0.5. Another reason for low correlations could be that $\mathrm{SO}_{2}$ shows nearly no seasonality. In contrast to this, $\mathrm{O}_{3}$ expresses the most significant seasonality of all investigated substances. As the model succeeded in modeling these seasonal concentration differences, only 3 out of 36 stations seemed to show no correlation at all. On the other hand, only seven stations showed a good correlation, which reflects the difficulties in modeling the short-term variability of ozone (Table 7).

Similar to ozone, nitrate $\left(\mathrm{NO}_{3}^{-}\right)$is not directly emitted from the engines, but rather is formed in the air by chemical reactions of $\mathrm{NO}_{2}$. Only about $5 \%$ of the fuel sulfur is emitted as sulfuric acid aerosol, whereas most of the particulate sulfate is produced in the atmosphere from $\mathrm{SO}_{2}$. Ammonium nitrate constitutes the major part of inorganic particulate matter. As the formation of these particulates is a complicated and not yet fully understood process, the model results are presumably less reliable than for gaseous compounds. Also, the sampling and measurement process is fairly complicated. The agreement between model and observations seemed to be better for nitrate than for sulfate. On the other hand, far fewer stations were available to evaluate the nitrate simulations (Tables 8 and 9). Six out of nine stations with nitrate measurements presented a correlation coefficient higher than 0.7 , while none of the 24 stations for sulfate did. The reason for this is probably the weak seasonality of sulfate in contrast to nitrate. The concentrations of particulate nitrate are notably dependent on ammonia concentrations in the atmosphere, and these are higher in summer than in winter. In contrast, particulate sulfate is nearly invariant to the concentration variations of ammonia.

In order to investigate differences when using the official EMEP emissions, we performed an additional base case run using the EMEP emissions for 2011 EMEP/CEIP (2015). 
Table 5. Comparison of simulated $\mathrm{NO}_{2}$ concentrations with observations in $\mu \mathrm{g} \mathrm{m}^{-3}$. Values that are significantly different between the base case and the no-ships case are printed in bold.

\begin{tabular}{|c|c|c|c|c|c|c|c|c|}
\hline \multirow[b]{2}{*}{ Station } & \multicolumn{3}{|c|}{ Base case } & \multicolumn{3}{|c|}{ No ships } & \multicolumn{2}{|c|}{ Observations } \\
\hline & Corr & NMB & Mean & Corr & NMB & Mean & Mean & No. of samples \\
\hline Offagne & 0.7 & -0.33 & 1.3 & 0.71 & -0.36 & 1.25 & 2.1 & 332 \\
\hline Eupen & 0.62 & 0 & 3.08 & 0.6 & -0.04 & 2.9 & 3.27 & 344 \\
\hline Vezin & 0.72 & -0.25 & 2.86 & 0.72 & -0.27 & 2.75 & 4.28 & 346 \\
\hline Westerland & 0.77 & -0.62 & 0.55 & 0.76 & -0.76 & 0.29 & 1.44 & 349 \\
\hline Waldhof & 0.83 & -0.43 & 1.13 & 0.82 & -0.47 & 1.05 & 2.37 & 350 \\
\hline Neuglobsow & 0.74 & -0.28 & 0.96 & 0.76 & -0.33 & 0.87 & 1.51 & 359 \\
\hline Schmücke & 0.71 & -0.16 & 1.38 & 0.71 & -0.18 & 1.35 & 1.79 & 355 \\
\hline Zingst & 0.72 & -0.38 & 1.1 & 0.61 & -0.61 & 0.54 & 1.95 & 359 \\
\hline Keldsnor & 0.71 & -0.39 & 1.2 & 0.57 & -0.67 & 0.49 & 2.04 & 344 \\
\hline Anholt & 0.65 & -0.45 & 0.72 & 0.45 & -0.73 & 0.3 & 1.38 & 322 \\
\hline Eskdalemuir & 0.45 & -0.41 & 0.62 & 0.44 & -0.45 & 0.57 & 1.41 & 364 \\
\hline Yarner Wood & 0.54 & -0.42 & 0.82 & 0.45 & -0.54 & 0.62 & 1.57 & 245 \\
\hline High Muffles & 0.72 & -0.09 & 1.27 & 0.71 & -0.14 & 1.14 & 1.57 & 287 \\
\hline Aston Hill & 0.64 & -0.21 & 0.97 & 0.64 & -0.26 & 0.89 & 1.6 & 295 \\
\hline Bush & 0.67 & -0.54 & 0.87 & 0.67 & -0.56 & 0.81 & 2.24 & 258 \\
\hline Harwell & 0.7 & -0.01 & 2.56 & 0.68 & -0.05 & 2.42 & 2.52 & 310 \\
\hline Ladybower Res. & 0.66 & 0.11 & 2.08 & 0.66 & 0.07 & 2.01 & 2.16 & 251 \\
\hline Lullington Heath & 0.65 & -0.31 & 1.54 & 0.53 & -0.46 & 1.05 & 2.52 & 360 \\
\hline Narberth & 0.56 & -0.66 & 0.31 & 0.55 & -0.75 & 0.18 & 1.42 & 350 \\
\hline Wicken Fen & 0.73 & -0.07 & 2.25 & 0.73 & -0.12 & 2.11 & 2.64 & 355 \\
\hline St. Osyth & 0.74 & -0.34 & 2.06 & 0.61 & -0.47 & 1.54 & 3.18 & 324 \\
\hline Market Harborough & 0.82 & -0.14 & 2 & 0.82 & -0.18 & 1.9 & 2.67 & 365 \\
\hline Eibergen & 0.8 & -0.36 & 2.39 & 0.81 & -0.39 & 2.23 & 4.64 & 361 \\
\hline Vredepeel & 0.79 & -0.45 & 3.06 & 0.78 & -0.47 & 2.89 & 6.49 & 365 \\
\hline Cabauw & 0.74 & -0.32 & 3.33 & 0.77 & -0.39 & 2.89 & 5.62 & 364 \\
\hline De Zilk & 0.77 & -0.44 & 2.03 & 0.78 & -0.55 & 1.38 & 4.18 & 337 \\
\hline Birkenes & 0.39 & 0.76 & 0.5 & 0.33 & 0.53 & 0.43 & 0.26 & 361 \\
\hline Hurdal & 0.46 & 3.04 & 2.1 & 0.44 & 2.98 & 2.05 & 0.45 & 360 \\
\hline Råö & 0.6 & -0.5 & 0.53 & 0.53 & -0.73 & 0.27 & 1.12 & 364 \\
\hline
\end{tabular}

Table 6. Comparison of simulated $\mathrm{SO}_{2}$ concentrations with observations in $\mu \mathrm{g} \mathrm{m}^{-3}$. Values that are significantly different between the base case and the no-ships case are printed in bold.

\begin{tabular}{lccc|ccc|cc}
\hline & \multicolumn{3}{c}{ Base case } & \multicolumn{3}{c|}{ No ships } & \multicolumn{2}{c}{ Observations } \\
Station & Corr & NMB & Mean & Corr & NMB & Mean & Mean & No. of samples \\
\hline Westerland & 0.45 & 0.17 & $\mathbf{0 . 2 1}$ & 0.44 & -0.15 & 0.08 & 0.32 & 242 \\
Waldhof & 0.53 & 0.85 & 0.47 & 0.53 & 0.76 & 0.41 & 0.31 & 237 \\
Neuglobsow & 0.58 & 0.48 & $\mathbf{0 . 3 4}$ & 0.61 & 0.37 & 0.27 & 0.29 & 240 \\
Schmücke & 0.65 & 0.4 & 0.58 & 0.66 & 0.37 & 0.55 & 0.49 & 311 \\
Zingst & $\mathbf{0 . 4 3}$ & 0.45 & $\mathbf{0 . 4 6}$ & 0.26 & -0.09 & 0.15 & 0.37 & 236 \\
Tange & 0.63 & 0.61 & $\mathbf{0 . 1 4}$ & 0.59 & 0.3 & 0.1 & 0.12 & 350 \\
Keldsnor & $\mathbf{0 . 6 8}$ & 0.53 & $\mathbf{0 . 4 9}$ & 0.54 & -0.06 & 0.19 & 0.35 & 339 \\
Anholt & $\mathbf{0 . 6 2}$ & 0.11 & $\mathbf{0 . 2 1}$ & 0.44 & -0.31 & 0.09 & 0.22 & 339 \\
Ulborg & 0.52 & 0.4 & $\mathbf{0 . 1 2}$ & 0.47 & 0.1 & 0.07 & 0.12 & 340 \\
Narberth & 0.07 & -0.78 & $\mathbf{0 . 2 2}$ & 0.05 & -0.85 & 0.1 & 1.64 & 245 \\
Wicken Fen & 0.33 & -0.2 & 1.34 & 0.33 & -0.23 & 1.29 & 2.11 & 363 \\
Bilthoven & 0.32 & 0.43 & 1.27 & 0.31 & 0.34 & 1.16 & 1.03 & 224 \\
Vredepeel & 0.49 & 1.38 & 1.25 & 0.48 & 1.32 & 1.19 & 0.65 & 251 \\
De Zilk & 0.45 & 0.45 & $\mathbf{1 . 2 7}$ & 0.42 & 0.32 & 1.04 & 1.2 & 254 \\
Råö & $\mathbf{0 . 3 8}$ & -0.25 & $\mathbf{0 . 1 5}$ & 0.23 & -0.5 & 0.07 & 0.26 & 346 \\
\hline
\end{tabular}


Table 7. Comparison of simulated $\mathrm{O}_{3}$ concentrations with observations in $\mu \mathrm{g} \mathrm{m}^{-3}$. Values that are significantly different between the base case and the no-ships case are printed in bold.

\begin{tabular}{|c|c|c|c|c|c|c|c|c|}
\hline \multirow[b]{2}{*}{ Station } & \multicolumn{3}{|c|}{ Base case } & \multicolumn{3}{|c|}{ No ships } & \multicolumn{2}{|c|}{ Observations } \\
\hline & Corr & NMB & Mean & Corr & $\mathrm{NMB}$ & Mean & Mean & No. of samples \\
\hline Westerland & 0.66 & 0.09 & 72.15 & 0.58 & 0.06 & 70.63 & 63.42 & 365 \\
\hline Waldhof & 0.75 & 0.28 & 64.57 & 0.74 & 0.26 & 63.88 & 45.73 & 365 \\
\hline Neuglobsow & 0.68 & 0.25 & 68.27 & 0.65 & 0.23 & 66.82 & 54.45 & 365 \\
\hline Schmücke & 0.69 & 0.04 & 67.81 & 0.69 & 0.03 & 67.25 & 64.21 & 365 \\
\hline Zingst & 0.68 & 0.29 & 70.37 & 0.62 & 0.26 & 68.94 & 54.62 & 365 \\
\hline Keldsnor & 0.69 & 0.22 & 71.34 & 0.62 & 0.19 & 69.62 & 58.29 & 365 \\
\hline Ulborg & 0.7 & 0.09 & 72.23 & 0.64 & 0.06 & 70.12 & 66.16 & 332 \\
\hline Lille Valby & 0.69 & 0.24 & 67.81 & 0.64 & 0.21 & 66.18 & 54.89 & 365 \\
\hline Eskdalemuir & 0.62 & 0.21 & 67.38 & 0.64 & 0.18 & 66.28 & 54.31 & 346 \\
\hline Yarner Wood & 0.53 & 0.22 & 74.37 & 0.54 & 0.2 & 73.26 & 60.84 & 344 \\
\hline High Muffles & 0.64 & 0.17 & 66.72 & 0.65 & 0.14 & 65.39 & 55.17 & 313 \\
\hline Strath Vaich Dam & 0.55 & -0.04 & 69.67 & 0.56 & -0.06 & 68.31 & 72.64 & 324 \\
\hline Aston Hill & 0.69 & 0.02 & 71.22 & 0.71 & 0 & 69.85 & 69.92 & 314 \\
\hline Great Dun Fell & 0.46 & 0.2 & 68.12 & 0.48 & 0.17 & 67 & 55.85 & 362 \\
\hline Harwell & 0.64 & 0.31 & 66.34 & 0.65 & 0.29 & 65.32 & 50.83 & 354 \\
\hline Ladybower Res. & 0.75 & 0.12 & 65.93 & 0.75 & 0.1 & 64.52 & 58.83 & 357 \\
\hline Lullington Heath & 0.62 & 0.22 & 72.57 & 0.6 & 0.21 & 72.12 & 59.69 & 359 \\
\hline Narberth & 0.49 & 0.26 & 76.52 & 0.51 & 0.23 & 75.05 & 60.03 & 267 \\
\hline Auchencorth Moss & 0.64 & 0.14 & 68.76 & 0.64 & 0.11 & 67.35 & 60.43 & 359 \\
\hline Weybourne & 0.71 & 0.07 & 64.45 & 0.71 & 0.05 & 64.18 & 60.3 & 361 \\
\hline St. Osyth & 0.63 & 0.29 & 69.5 & 0.59 & 0.29 & 69.45 & 53.91 & 336 \\
\hline Market Harborough & 0.78 & 0.16 & 65.77 & 0.78 & 0.14 & 64.6 & 56.5 & 365 \\
\hline Lerwick & 0.54 & 0.02 & 70.51 & 0.5 & 0 & 69.03 & 68.44 & 356 \\
\hline Eibergen & 0.78 & 0.65 & 59.75 & 0.78 & 0.63 & 59.58 & 31.78 & 357 \\
\hline Kollumerwaard & 0.71 & 0.31 & 69.08 & 0.71 & 0.29 & 67.94 & 52.85 & 348 \\
\hline Vredepeel & 0.7 & 0.51 & 70.27 & 0.7 & 0.49 & 69.23 & 46.43 & 286 \\
\hline Cabauw & 0.69 & 0.56 & 70.25 & 0.69 & 0.54 & 69.43 & 44.95 & 281 \\
\hline De Zilk & 0.63 & 0.49 & 71.18 & 0.64 & 0.48 & 70.65 & 47.72 & 312 \\
\hline Birkenes & 0.5 & 0.2 & 65.86 & 0.46 & 0.17 & 63.97 & 54.76 & 353 \\
\hline Prestebakke & 0.59 & 0.13 & 64.69 & 0.55 & 0.09 & 62.66 & 57.43 & 365 \\
\hline Sandve & 0.62 & 0.07 & 71.36 & 0.58 & 0.03 & 68.8 & 66.57 & 365 \\
\hline Hurdal & 0.51 & 0.06 & 54.01 & 0.51 & 0.04 & 52.87 & 50.76 & 365 \\
\hline Bredkälen & 0.46 & -0.07 & 52.69 & 0.46 & -0.09 & 51.76 & 56.76 & 356 \\
\hline Råö & 0.62 & 0.13 & 69.84 & 0.54 & 0.09 & 67.35 & 61.65 & 365 \\
\hline Norra-Kvill & 0.56 & 0.03 & 61.83 & 0.5 & 0 & 59.99 & 58.07 & 365 \\
\hline Grimsö & 0.54 & 0.11 & 57.86 & 0.52 & 0.08 & 56.42 & 52.18 & 365 \\
\hline
\end{tabular}

It turned out that the simulation results differ only a little. At the stations along the North Sea coast that showed significant differences between the base case and the no-ships case (Table 5), the median annual difference for $\mathrm{NO}_{2}$ was $0.09 \mu \mathrm{g} \mathrm{m}^{-3}$. Thus, it cannot be clearly decided which model performs better.

\subsubsection{Differences between the base case and the no-ships-emissions case}

It is evident that ship emissions increase the background concentrations of pollutants at the coast. Therefore, the model bias of the underpredicted substances like $\mathrm{NO}_{2}$ decreases at coastal stations if ship emissions are taken into account.

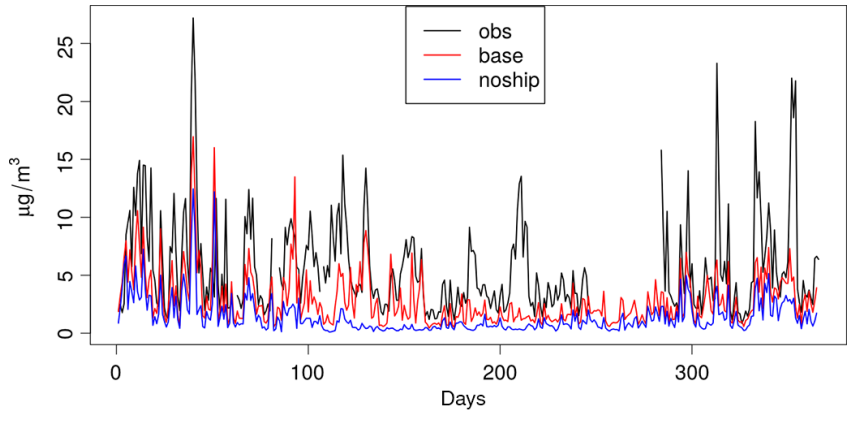

Figure 7. $\mathrm{NO}_{2}$ concentration time series at Anholt. 
Table 8. Comparison of simulated $\mathrm{NO}_{3}^{-}$concentrations with observations in $\mu \mathrm{g} \mathrm{m}^{-3}$. Values that are significantly different between the base case and the no-ships case are printed in bold.

\begin{tabular}{lccc|ccc|cc}
\hline & \multicolumn{3}{c}{ Base case } & \multicolumn{3}{c|}{ No ships } & \multicolumn{2}{c}{ Observations } \\
Station & Corr & NMB & Mean & Corr & NMB & Mean & Mean & No. of samples \\
\hline Waldhof & 0.71 & -0.06 & 0.22 & 0.71 & -0.16 & 0.18 & 0.32 & 236 \\
Neuglobsow & 0.75 & 0.16 & $\mathbf{0 . 1 9}$ & 0.75 & 0.03 & 0.15 & 0.3 & 234 \\
Zingst & 0.74 & -0.13 & $\mathbf{0 . 2 4}$ & 0.72 & -0.29 & 0.16 & 0.45 & 235 \\
Oak Park & 0.84 & -0.15 & $\mathbf{0 . 0 9}$ & 0.82 & -0.27 & 0.07 & 0.17 & 255 \\
Malin Head & 0.8 & -0.31 & $\mathbf{0 . 0 6}$ & 0.78 & -0.4 & 0.04 & 0.11 & 310 \\
Carnsore Point & 0.81 & -0.38 & $\mathbf{0 . 0 7}$ & 0.79 & -0.47 & 0.06 & 0.19 & 347 \\
Kollumerwaard & 0.56 & 0.07 & $\mathbf{0 . 5 8}$ & 0.53 & -0.07 & 0.44 & 0.79 & 239 \\
Birkenes & 0.35 & -0.16 & $\mathbf{0 . 0 5}$ & 0.34 & -0.3 & 0.04 & 0.1 & 298 \\
Hurdal & 0.26 & 1.28 & 0.1 & 0.26 & 1.06 & 0.09 & 0.07 & 295 \\
\hline
\end{tabular}

This can be shown exemplarily for the Danish island of Anholt (Fig. 7), where the NMB changed from -0.69 to -0.37 (Table 5). Some peaks that had been missed by the simulations without ship emissions were met. For this reason, not only the bias decreased, but the correlation also increased at some stations if ship emissions were included. The significance of the increase in correlation between simulations and observations was tested by calculating the Fisher $z$ transformation of the two correlation coefficients for the different model runs and testing the alternative hypothesis "greater than" at a significance level of 0.9. This means it was accepted that the correlation at a certain station increased by including ship emissions if the probability of this assumption was larger than $90 \%$. The significance of the difference of model biases was validated by performing a one-sided $t$ test between the model results with and without including ship emissions. As mentioned above, values were logarhithmized if necessary. It can be stated that those stations where bias and correlation were enhanced significantly are most likely to be influenced by ship emissions.

Concerning $\mathrm{NO}_{2}$, significant correlation increases could be stated for Zingst, Keldsnor, Anholt, Yarner Wood, Lullington Heath, St. Osyth and Råö - the latter also lying on an island like Anholt. In the densely populated Netherlands and Belgium where concentrations are generally higher than in other coastal regions around the North Sea, the relative contribution of ships was quite small. Actually, no significant concentration increase could be found for the Belgian stations, and in the Netherlands an increase could only be found for stations close to the sea. For the rest of the studied area, all stations close to the sea showed concentration increases, even Neu Globsow in the German hinterland.

Only four stations in the Baltic Sea (the most western part of the Baltic Sea was also in the model domain) showed significantly increased correlations concerning $\mathrm{SO}_{2}$. However, stations that showed increased $\mathrm{NO}_{2}$ concentrations also showed increased $\mathrm{SO}_{2}$ concentrations, which underlines the influence of ships for these sites. When looking at $\mathrm{O}_{3}$, one would expect that the correlations only were increased at those stations where $\mathrm{NO}_{2}$ also had a better correlation. There were, however, three stations, Westerland, Zingst and Ulborg, where increased correlations for ozone could be verified, but not for $\mathrm{NO}_{2}$. This can neither be unambiguously explained by ship emissions nor by the model chemistry. On the one hand, $\mathrm{O}_{3}$ lives longer than $\mathrm{NO}_{2}$, which could be the reason that the ship influence is easier to detect with $\mathrm{O}_{3}$. On the other hand, the three mentioned measurement stations lie close to the shipping lanes and the atmospheric lifetime of the substances might not play such a big role. Therefore, the ambiguities could also be an issue of the measurement data. There were in total eight stations with increased ozone correlations, all of them placed close to the sea.

It was already mentioned that it is both difficult to model and to measure particulate $\mathrm{NO}_{3}^{-}$, and therefore it is no surprise that no significant increase in correlation coefficients between the two model runs could be confirmed. The same can be said about particulate sulfate, with one exception at Keldsnor. All stations where the modeled $\mathrm{NO}_{2}$ concentrations increase significantly also presented significantly increased nitrate concentrations. The same relation would be expected between $\mathrm{SO}_{2}$ and sulfate. It could, however, not be confirmed for stations Waldhof, Birkenes and Vredepeel. In this regard, it should be mentioned that results of statistical testing only allow one to state that the effect could not be verified. They are always dependent on the underlying data and do not necessarily reflect reality. Still, it can be generalized that the concentration levels for particulates increased at stations close to the shipping lanes.

\subsection{Concentration patterns over northwestern Europe}

The highest pollutant concentrations typically occurred over land in highly populated or industrialized areas. Some of these areas in France, Belgium, Holland and the UK lie relatively close to the shore and therefore experienced moderate concentration increases by ship emissions. While sites east of the English Channel showed increases of about $10 \%$, much smaller increases were calculated along the eastern coast of 


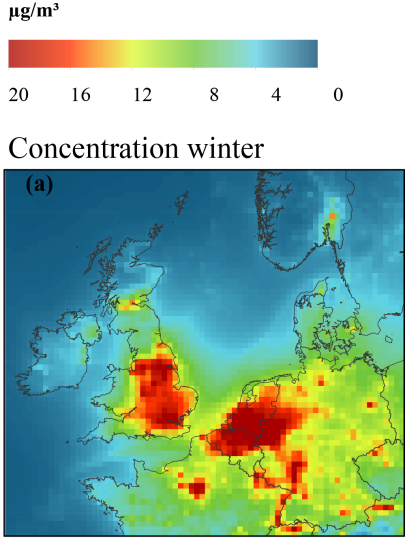

Concentration summer

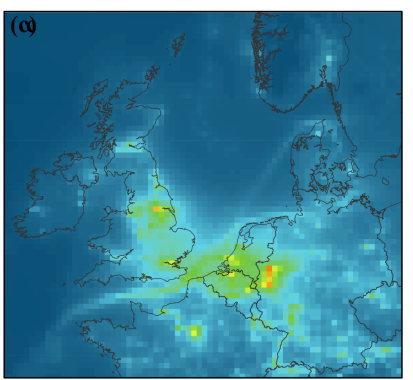

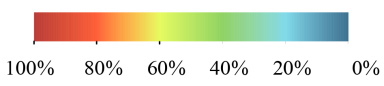

Contribution from ships winter

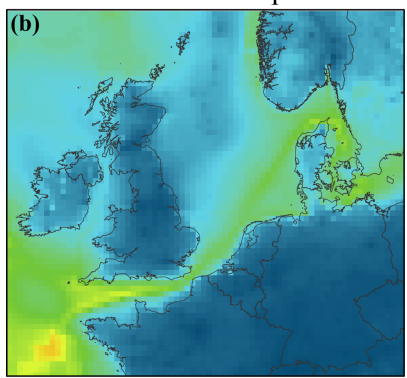

Contribution from ships summer

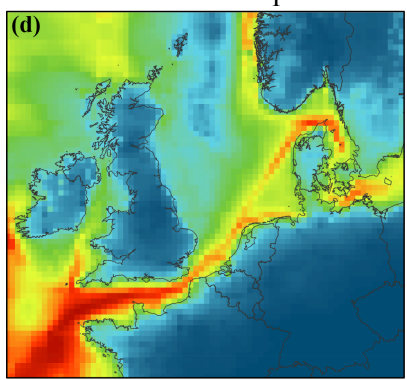

Figure 8. $\mathrm{NO}_{2}$ in summer and winter and the relative contribution of ship emissions.

the UK (see for example $\mathrm{NO}_{2}$, Fig. 8). The reason is that pollutant plumes from the shipping lanes passing the English Channel are transported towards the continent by the prevailing westerly and southwesterly wind directions. During this transport, they are partly removed from the atmosphere by wet and dry deposition. In less populated areas such as Scotland and large parts of Scandinavia, pollution levels were generally lower than in the regions mentioned above. This is why the relative pollution increase by ships was up to $50 \%$ in summer and between 10 and $20 \%$ in winter. Apart from the presence of other sources, the relative influence of ship exhaust on air pollutant concentrations also depends on the reaction rates of primary pollutants to form secondary pollutants. These are higher at higher temperatures, which would increase concentrations of secondary pollutants in summer and decrease them in winter. On the other hand, the coagulation of particulates is facilitated at lower temperatures, which would suggest lower concentrations of particle-bound secondary pollutants like $\mathrm{NO}_{3}^{-}$and $\mathrm{SO}_{4}^{2-}$ in summer. Northern Germany and Denmark can be considered coastal regions and are surrounded by numerous shipping lanes. Here, the contribution of shipping emissions to $\mathrm{NO}_{2}$ is around $15 \%$ in winter and $25 \%$ in summer. Similarly, the contributions relating to $\mathrm{SO}_{2}$ are about $12 \%$ in winter and $30 \%$ in summer (Fig. 9). Some hundred kilometers away from the sea in the German hinterland, the contributions to $\mathrm{SO}_{2}$ are $5 \%$ in summer and $2 \%$ in winter, while for the secondary particu-

$\mu \mathrm{g} / \mathrm{m}^{3}$
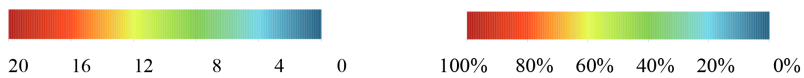

Concentration winter

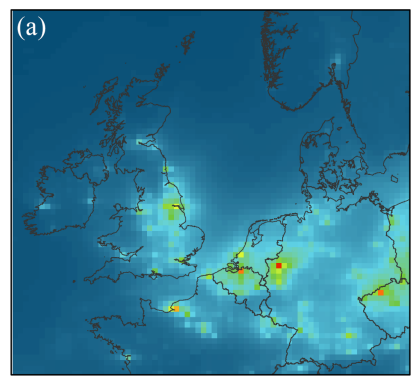

Concentration summer

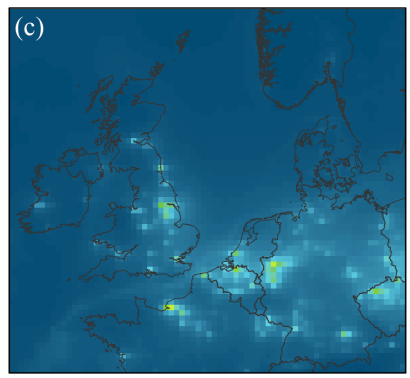

Contribution from ships winter

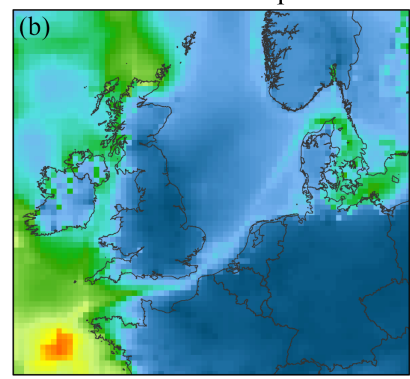

Contribution from ships summer

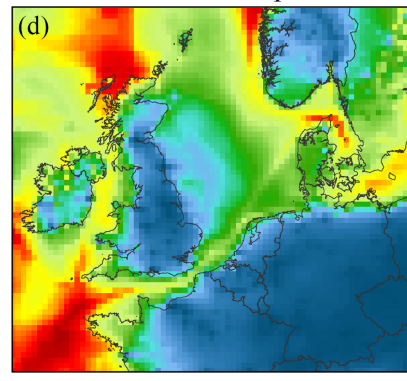

Figure 9. $\mathrm{SO}_{2}$ in summer and winter and the relative contribution of ship emissions.

late sulfate the contributions are $8 \%$ in summer and $3 \%$ in winter (Fig. 10).

Along the major shipping lanes between the UK and Germany the pollution levels were comparable to those of moderately polluted regions in Europe. However, the concentration maps (Figs. 8 through 14) indicated that nowhere in the investigated domain was the contribution of ship emissions to any pollutant $100 \%$. This means that emissions produced ashore and substances that enter the domain through the boundaries were transported over the North Sea. Where these influences were low, the contributions of ship emissions were the highest, provided ships operated in these regions. The most significant example of this was the western entrance to the English Channel where the ship emissions were responsible for over $90 \%$ of $\mathrm{NO}_{2}$ and $\mathrm{SO}_{2}$ concentrations.

\subsection{1 $\mathrm{NO}_{2}$ and $\mathrm{SO}_{2}$}

While for $\mathrm{NO}_{2}$ and $\mathrm{SO}_{2}$ the overall concentrations were higher in the colder months, Figs. 8 and 9 suggest that the absolute contribution of ships is lower in these months. One of the largest sources of land-based pollution is heating, which is subject to seasonality. Therefore, the relative contribution of ship engines to pollution levels is lower in winter than in summer because, while the shipping activity is only slightly higher in summer, significantly more pollution from landbased sources is produced in winter than in summer. Due to 


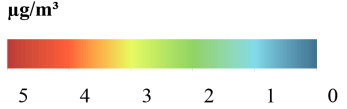

Concentration winter

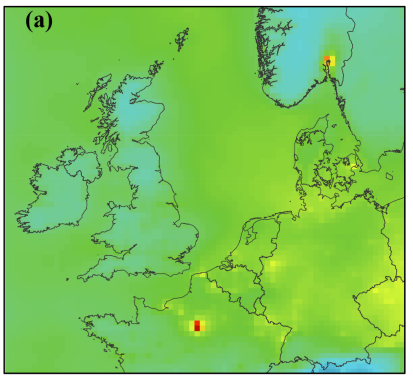

Concentration summer

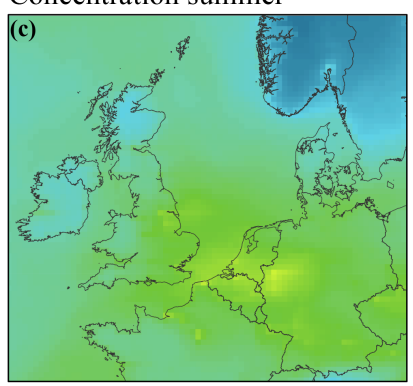

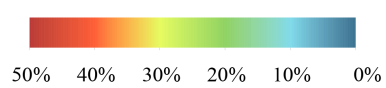

Contribution from ships winter

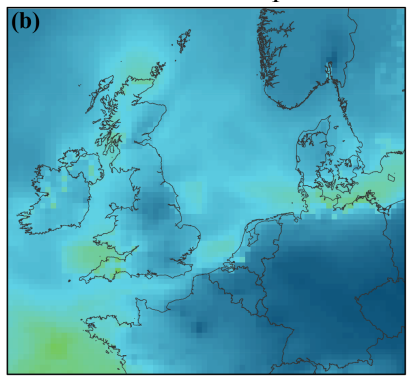

Contribution from ships summer

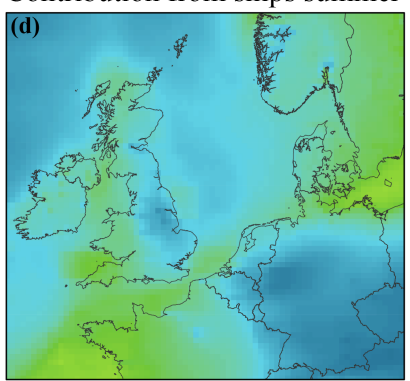

Figure 10. $\mathrm{SO}_{4}^{2-}$ in summer and winter and the relative contribution of ship emissions.

the relatively high emissions of land-based sources in winter, only slight concentration changes over land in a small slice at the land-sea border were noticeable. In summer, this slice was a little broader, indicating that the shipping influence could be recognized further inland than in winter. $\mathrm{SO}_{2}$ concentrations were a little lower than $\mathrm{NO}_{2}$ concentrations. The relative contribution of ships within the North Sea was also a little lower, with the general spatial pattern being similar. However, the influence of ships was high at the northern and western domain borders because there, ships are allowed to use fuel with higher sulfur content.

\subsection{2 $\quad \mathrm{PM}_{2.5}$}

The maps of simulated $\mathrm{PM}_{2.5}$ concentrations suggested in some regions a large relative contribution from ships in the summer months, even far inland. This emphasized the fact that the influence of ship emissions on particulate matter in general could be seen further away from the shipping lanes than is the case for $\mathrm{NO}_{2}$ and $\mathrm{SO}_{2}$, the most important precursors of these secondary pollutants. The influence of ship emissions was further emphasized by the fact that concentration peaks in the time series (Fig. 12) were accompanied by relatively large reductions if ship emissions had been omitted. The main constituents of $\mathrm{PM}_{2.5}$ are ammonium sulfate and ammonium nitrate, whereas nitrate and sulfate originate from oxidation of $\mathrm{NO}_{2}$ and $\mathrm{SO}_{2}$. While these oxidation re-

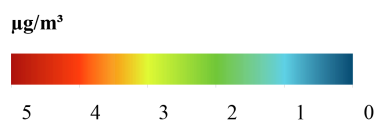

Concentration winter

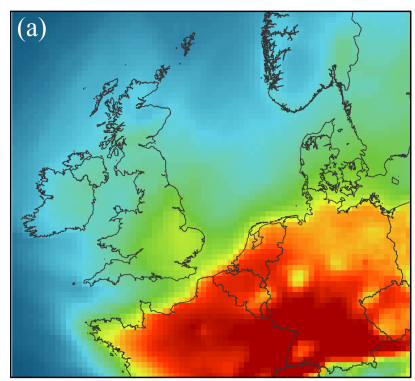

Concentration summer
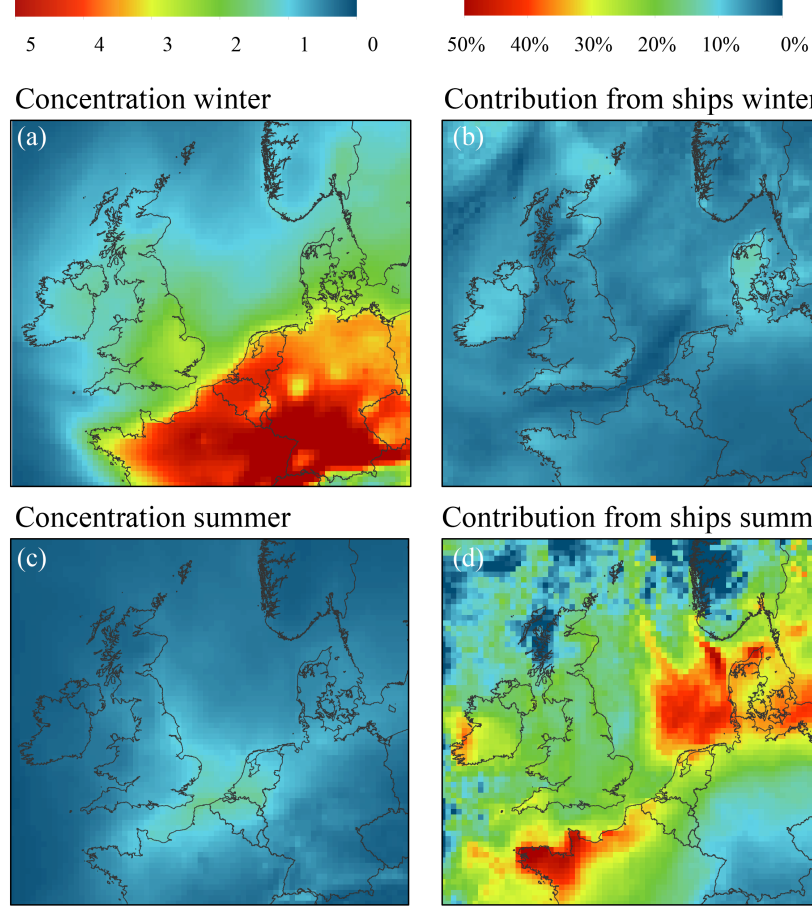

Contribution from ships winter

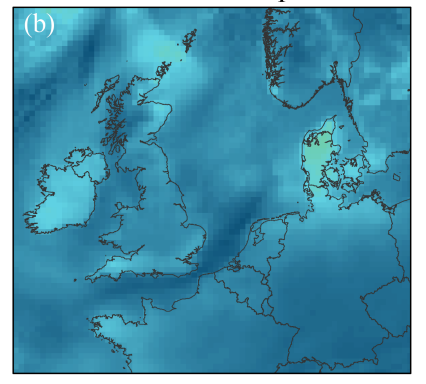

Contribution from ships summer

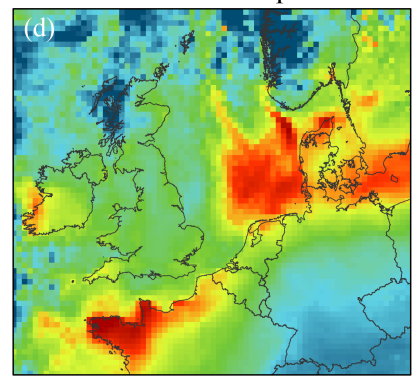

Figure 11. $\mathrm{NO}_{3}^{-}$in summer and winter and the relative contribution of ship emissions.

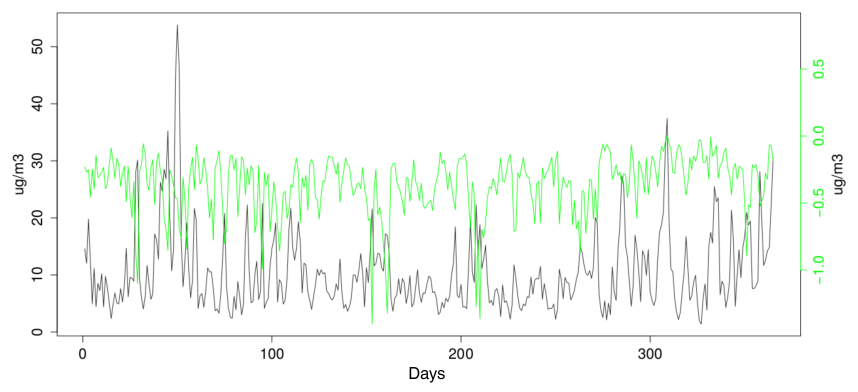

Figure 12. $\mathrm{PM}_{2.5}$ time series. Concentrations averaged over the Dutch and Belgian coasts (area 4 ) and the negative bias if ship emissions were excluded.

actions are taking place, the pollutant plumes can be transported inland (Fig. 13). The reaction rates depend, however, on temperature, solar radiation and the availability of reaction partners like $\mathrm{OH}$ and $\mathrm{NH}_{3}$, which means that the reaction conditions are much better in summer than in winter. Furthermore, ammonia emissions are lower in winter, which additionally limits the formation of ammonium nitrate and enhances the dry deposition of gaseous nitric acid. Low ammonia emissions, however, have no effect on ammonium sulfate because under ammonia-limited conditions the ammonium sulfate production is preferred over ammonium nitrate production. 
Table 9. Comparison of simulated $\mathrm{SO}_{4}^{2-}$ concentrations with observations in $\mu \mathrm{g} \mathrm{m}^{-3}$. Values that are significantly different between the base case and the no-ships case are printed in bold.

\begin{tabular}{lccc|ccc|cc}
\hline & \multicolumn{3}{c}{ Base case } & \multicolumn{3}{c}{ No ships } & \multicolumn{2}{c}{ Observations } \\
Station & Corr & NMB & Mean & Corr & NMB & Mean & Mean & No. of samples \\
\hline Westerland & 0.55 & -0.04 & $\mathbf{0 . 6 1}$ & 0.52 & -0.14 & 0.54 & 0.62 & 242 \\
Waldhof & 0.5 & -0.25 & $\mathbf{0 . 5 6}$ & 0.49 & -0.3 & 0.51 & 0.7 & 236 \\
Neuglobsow & 0.48 & -0.18 & $\mathbf{0 . 5 4}$ & 0.47 & -0.26 & 0.48 & 0.64 & 240 \\
Zingst & 0.52 & -0.13 & $\mathbf{0 . 6}$ & 0.47 & -0.29 & 0.47 & 0.64 & 241 \\
Tange & 0.55 & -0.04 & $\mathbf{0 . 4 5}$ & 0.5 & -0.13 & 0.41 & 0.44 & 355 \\
Keldsnor & $\mathbf{0 . 5 6}$ & -0.07 & $\mathbf{0 . 6}$ & 0.48 & -0.22 & 0.49 & 0.61 & 340 \\
Anholt & 0.6 & -0.12 & $\mathbf{0 . 4 8}$ & 0.54 & -0.22 & 0.41 & 0.53 & 339 \\
Ulborg & 0.45 & 0.05 & $\mathbf{0 . 5 4}$ & 0.39 & -0.03 & 0.49 & 0.48 & 353 \\
Eskdalemuir & 0.43 & 0.3 & $\mathbf{0 . 3 9}$ & 0.39 & 0.18 & 0.36 & 0.26 & 333 \\
Lough Navar & 0.29 & 0.41 & $\mathbf{0 . 3 8}$ & 0.26 & 0.3 & 0.34 & 0.22 & 213 \\
Barcombe Mills & 0.48 & -0.11 & $\mathbf{0 . 5 9}$ & 0.45 & -0.2 & 0.52 & 0.59 & 280 \\
Yarner Wood & 0.52 & 0.03 & $\mathbf{0 . 5 3}$ & 0.45 & -0.11 & 0.45 & 0.42 & 268 \\
High Muffles & 0.41 & 0.32 & $\mathbf{0 . 4 9}$ & 0.33 & 0.21 & 0.45 & 0.34 & 232 \\
Oak Park & 0.5 & -0.02 & $\mathbf{0 . 4}$ & 0.44 & -0.11 & 0.36 & 0.34 & 257 \\
Malin Head & 0.5 & -0.07 & $\mathbf{0 . 4 4}$ & 0.46 & -0.15 & 0.4 & 0.44 & 335 \\
Carnsore Point & 0.58 & -0.18 & $\mathbf{0 . 5}$ & 0.56 & -0.25 & 0.45 & 0.58 & 348 \\
Bilthoven & 0.41 & 0.1 & $\mathbf{0 . 6 7}$ & 0.39 & 0.02 & 0.62 & 0.51 & 308 \\
Kollumerwaard & 0.37 & 0.15 & $\mathbf{0 . 5 9}$ & 0.32 & 0.05 & 0.53 & 0.43 & 348 \\
Vredepeel & 0.35 & 0.17 & $\mathbf{0 . 7}$ & 0.36 & 0.11 & 0.66 & 0.49 & 322 \\
De Zilk & 0.34 & 0.29 & $\mathbf{0 . 6 9}$ & 0.29 & 0.16 & 0.62 & 0.43 & 351 \\
Birkenes & 0.41 & 0.37 & $\mathbf{0 . 3 5}$ & 0.35 & 0.28 & 0.32 & 0.2 & 347 \\
Hurdal & 0.21 & 1.23 & 0.37 & 0.18 & 1.11 & 0.34 & 0.15 & 359 \\
Bredkälen & 0.26 & 0.69 & $\mathbf{0 . 2 3}$ & 0.24 & 0.54 & 0.21 & 0.12 & 334 \\
Råö & 0.63 & -0.21 & $\mathbf{0 . 4 3}$ & 0.6 & -0.28 & 0.38 & 0.52 & 357 \\
\hline & & & & & & & &
\end{tabular}

Table 10. Annual number of exceedances of the ozone threshold of $120 \mu \mathrm{g} \mathrm{m}^{-3}$. For the regions represented, see Fig. 1 .

\begin{tabular}{lrrrrr}
\hline & Region 1 & Region 2 & Region 3 & Region 4 & Region 5 \\
\hline All emissions & 9 & 19 & 27 & 46 & 29 \\
Without ships & 4 & 6 & 14 & 42 & 18 \\
\hline
\end{tabular}

\subsubsection{Ozone}

The formation of ozone is, most of all, driven by solar radiation and temperature. Thus, there is a clear summer to winter gradient. It is also evident that the contribution of ships can selectively be very significant, both in terms of increasing the $\mathrm{O}_{3}$ levels noticeably and decreasing them. The latter is the case in the English Channel, where massive emissions of $\mathrm{NO}_{x}$ in the absence of VOCs result in degradation of ozone. Figure 14 illustrates that ozone concentrations were increased by more than $10 \%$ along the Scandinavian coasts where no other relevant $\mathrm{NO}_{x}$ sources but enough VOC was present to form additional ozone.

For the purpose of assessing air quality, ozone concentrations are usually denoted as $8 \mathrm{~h}$ maximum concentrations. This is the maximum of $8 \mathrm{~h}$ means calculated as the gliding average for 1 day. A value of $120 \mu \mathrm{g} \mathrm{m}^{-3}$ was recom- mended by WHO in 2000 as the value below which health risks are low. The same value has been defined as a target value in the EU recommending that it should not be exceeded on more than 25 days per year within 3 subsequent years. An analysis of the daily $8 \mathrm{~h}$ maximum ozone values in selected coastal regions around the North Sea (Fig. 1) revealed that, in Germany, the Netherlands, Belgium and the UK a concentration of $120 \mu \mathrm{g} \mathrm{m}^{-3}$ was exceeded on more than 25 days (Table 10). Excluding shipping emissions reduced this number significantly in the UK and in Germany. In the Netherlands and Belgium, the effects were much smaller because of the high $\mathrm{NO}_{x}$ emissions from other sources.

\section{Summary and conclusions}

A multi-model approach to evaluating the impact of shipping on air quality was developed and applied to the North Sea and its bordering states for the year 2011. This approach involved developing a bottom-up emissions model for sea-going ships and integrating this into a well-established modeling system (COSMO-CLM, SMOKE-EU and CMAQ) to simulate atmospheric transport and chemical transformations of the emitted pollutants. 


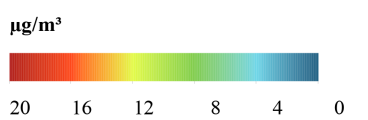

Concentration winter

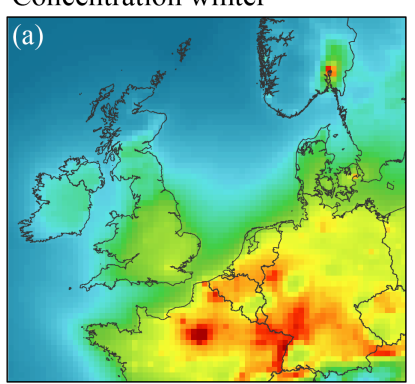

Concentration summer

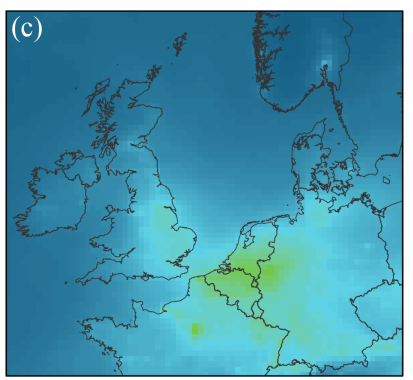

Figure 13. $\mathrm{PM}_{2.5}$ in summer and winter and the relative contribution of ship emissions.

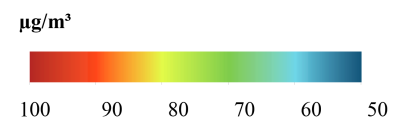

Concentration winter

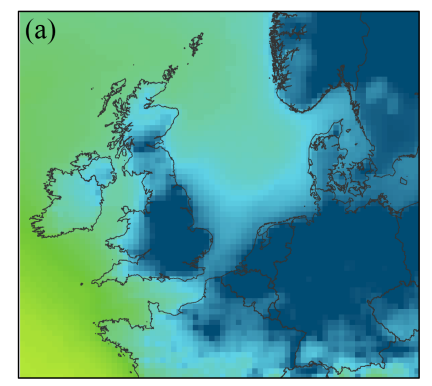

Concentration summer
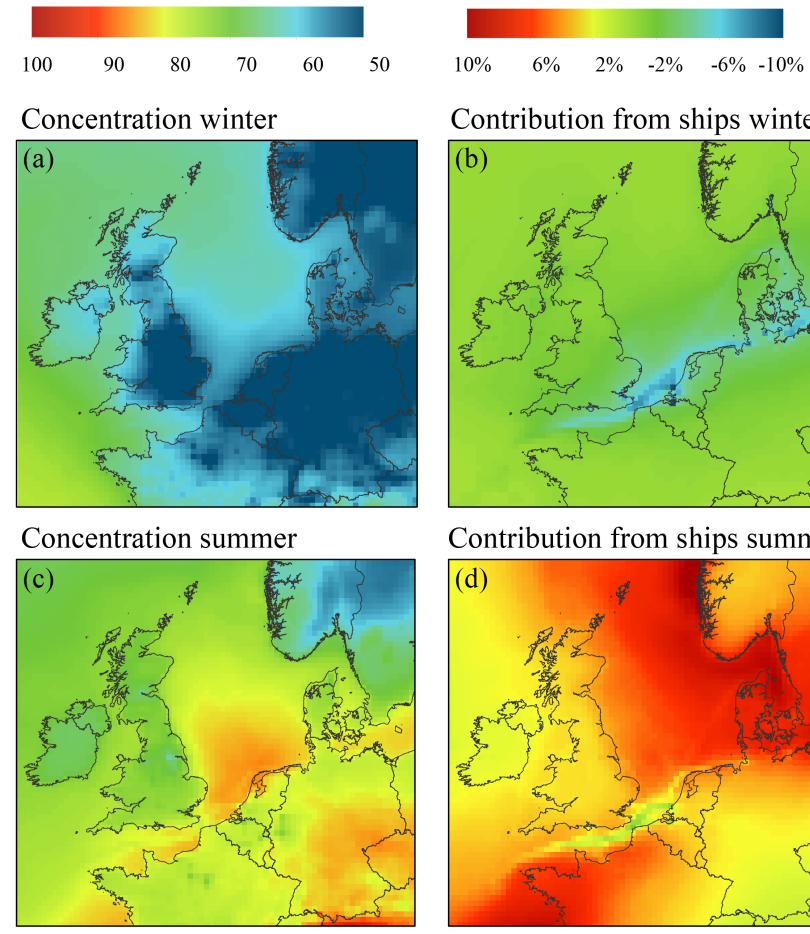

Contribution from ships winter

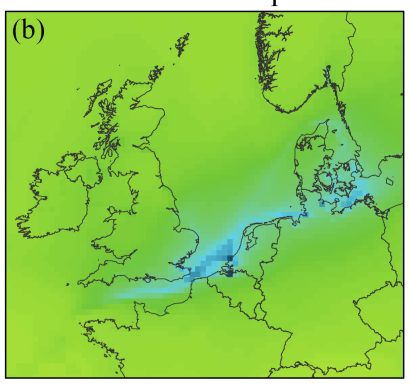

Contribution from ships summer

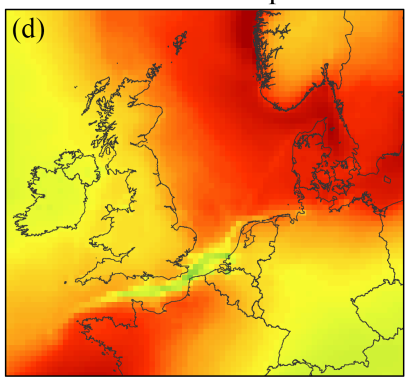

Figure 14. $\mathrm{O}_{3}$ in summer and winter and the relative contribution of ship emissions.
It is evident that the predictive ability of the modeling system for compounds that tend to be underestimated by the model improves by including ship emissions - particularly in coastal regions. An evaluation of the correlation and the bias between measured and modeled concentrations suggested that the agreement between model and observations improved generally at coastal stations. The less polluted a measurement site is by land-based sources like traffic or industry, the more enhancement of the prediction could be observed. This underlines both the necessity to include a proper representation of shipping emissions in emission inventories for air quality modeling and the plausibility of the model presented here.

The greatest benefit of an advanced bottom-up approach like the one presented here is the possibility to use it for creating and evaluating sophisticated emission scenarios (Matthias et al., 2016).

Running the CMAQ chemistry transport model with and without including ships in the emission inventory revealed that high relative contributions to primary gaseous pollutants concentrated at hotspots along the main shipping lanes. At the same time, the relative contribution to secondary pollutants like particulates and ozone was lower but distributed over a larger area. Even if the contribution of ships to concentration levels of air pollutants in densely populated areas is low, it is possible that ship emissions raise the background concentrations sufficiently high so that threshold values are more likely to be exceeded and air pollution standards missed. 
Appendix A: Supplementary information on ship engine characteristics and emission factor functions

\section{A1 Median engine characteristics per ship type and class}

The tables summarize class medians of characteristics for ship engines. MCR is the maximum continuous rating in $\mathrm{kW}$, speed the vessel's design speed in $\mathrm{kn}, \mathrm{RPM}$ the engine speed in revolutions per minute, $Y$ the year of build and power aux the installed power of auxiliary engines in $\mathrm{kW}$.

Table A1. Class medians for cargo ships.

\begin{tabular}{lrrrrrr}
\hline Class & GT & MCR & Speed & RPM & $Y$ & Power aux \\
\hline 1 & $<100$ & - & - & - & - & - \\
2 & $<1600$ & - & - & - & - & - \\
3 & $<3000$ & 749 & 11.5 & 750 & 1995 & 328 \\
4 & $<5000$ & 2400 & 12.5 & 600 & 1997 & 550 \\
5 & $<10000$ & 4690 & 15.5 & 500 & 2004 & 1213 \\
6 & $<30000$ & 10400 & 19 & 127 & 2002 & 2284 \\
7 & $<60000$ & 21068 & 22 & 104 & 2005 & 7400 \\
8 & $<100000$ & 57100 & 25 & 102 & 2005 & 9416 \\
9 & $\geq 100000$ & 68640 & 24.9 & 104 & 2010 & 13188 \\
\hline
\end{tabular}

Table A2. Class medians for bulk carriers.

\begin{tabular}{lrrrrrr}
\hline Class & GT & MCR & Speed & RPM & $Y$ & Power aux \\
\hline 1 & $<100$ & - & - & - & - & - \\
2 & $<1600$ & 882 & 11.5 & 574 & 1977 & 216 \\
3 & $<3000$ & 882 & 11 & 428 & 1977 & 390.5 \\
4 & $<5000$ & 2794 & 12.4 & 530 & 1977 & 435.5 \\
5 & $<10000$ & 3884 & 13.5 & 228.5 & 2002 & 735 \\
6 & $<30000$ & 7080 & 14 & 127 & 2002 & 1595 \\
7 & $<60000$ & 9480 & 14.5 & 113 & 2008 & 1890 \\
8 & $<100000$ & 16860 & 14.5 & 91 & 2009 & 2400 \\
9 & $\geq 100000$ & 22700 & 14.5 & 78 & 2009 & 6343 \\
\hline
\end{tabular}

Table A3. Class medians for tankers.

\begin{tabular}{lrrrrrr}
\hline Class & GT & MCR & Speed & RPM & $Y$ & Power aux \\
\hline 1 & $<100$ & - & - & - & - & - \\
2 & $<1600$ & 809 & 11 & 413 & 1985 & 307.5 \\
3 & $<3000$ & 809 & 12 & 720 & 1994 & 852 \\
4 & $<5000$ & 2640 & 13 & 600 & 1996 & 1201 \\
5 & $<10000$ & 4440 & 14 & 210 & 2002 & 1845 \\
6 & $<30000$ & 8562 & 14.5 & 127 & 2003 & 2826.5 \\
7 & $<60000$ & 12240 & 14.9 & 105 & 2005 & 2768 \\
8 & $<100000$ & 16859 & 15.3 & 92 & 1999 & 2999 \\
9 & $\geq 100000$ & 28972.5 & 16 & 79 & 2002 & 4828 \\
\hline
\end{tabular}

Table A4. Class medians for cruise ships. As the majority of the cruise ships use their main engines instead of auxiliary engines to generate electricity, $40 \%$ of the MCR was used as the total power of auxiliary engines. The value of $40 \%$ was derived from evaluating cruise ships with no diesel electric engines.

\begin{tabular}{lrrrrrr}
\hline Class & GT & MCR & Speed & RPM & $Y$ & Power aux \\
\hline 1 & $<100$ & - & - & - & - & - \\
2 & $<1600$ & - & - & - & - & - \\
3 & $<3000$ & 1060 & 12 & 1175 & 2001 & - \\
4 & $<5000$ & 3520 & 15.75 & 1000 & 1998 & - \\
5 & $<10000$ & 5516 & 16 & 750 & 1987 & - \\
6 & $<30000$ & 13232 & 18.9 & 520 & 1996 & - \\
7 & $<60000$ & 23514 & 20 & 600 & 1984 & - \\
8 & $<100000$ & 57500 & 22 & 514 & 2006 & - \\
9 & $\geq 100000$ & 71400 & 22 & 514 & 2006 & - \\
\hline
\end{tabular}

Table A5. Class medians for ferries.

\begin{tabular}{lrrcrrr}
\hline Class & GT & MCR & Speed & RPM & $Y$ & Power aux \\
\hline 1 & $<100$ & 409 & 12.8 & 2100 & 1995 & 174 \\
2 & $<1600$ & 1900 & 12.8 & 1800 & 1978 & 174 \\
3 & $<3000$ & 1900 & 15 & 1050 & 1987 & 715 \\
4 & $<5000$ & 5884 & 17.5 & 850 & 2004 & 1292 \\
5 & $<10000$ & 8000 & 17.5 & 600 & 1997 & 1768 \\
6 & $<30000$ & 15479 & 20 & 510 & 1994 & 3785 \\
7 & $<60000$ & 30400 & 22 & 500 & 1988 & 6720 \\
8 & $<100000$ & 32400 & 21.9 & 1225 & 1986 & 6153 \\
9 & $\geq 100000$ & - & - & - & - & - \\
\hline
\end{tabular}

Table A6. Class medians for tugs.

\begin{tabular}{lrrrrrr}
\hline Class & GT & MCR & Speed & RPM & $Y$ & Power aux \\
\hline 1 & $<100$ & 882.5 & 10.2 & 1800 & 2000 & 48 \\
2 & $<1600$ & 2940 & 12 & 1000 & 2004 & 315 \\
3 & $<3000$ & 2940 & 13.25 & 750 & 2007 & 1060 \\
4 & $<5000$ & 12000 & 14 & 750 & 2008 & 1222.5 \\
5 & $<10000$ & 16320 & 16.75 & 750 & 2008 & 2482 \\
6 & $<30000$ & - & - & - & - & - \\
7 & $<60000$ & - & - & - & - & - \\
8 & $<100000$ & - & - & - & - & - \\
9 & $\geq 100000$ & - & - & - & - & - \\
\hline
\end{tabular}

Table A7. Class medians for other vessels where no type specification could be found.

\begin{tabular}{lrrrrrr}
\hline Class & GT & MCR & Speed & RPM & $Y$ & Power aux \\
\hline 1 & $<100$ & 932 & 11 & 2100 & 1980 & 70.5 \\
2 & $<1600$ & 1618 & 12 & 1800 & 1983 & 391 \\
3 & $<3000$ & 1618 & 12.8 & 1000 & 1994 & 1065 \\
4 & $<5000$ & 5280 & 14 & 750 & 1990 & 978 \\
5 & $<10000$ & 8632 & 14.4 & 750 & 2001 & 930 \\
6 & $<30000$ & 12942.5 & 14.6 & 720 & 1998 & 1648 \\
7 & $<60000$ & 30156 & 14.1 & 500 & 2008 & 1007 \\
8 & $<100000$ & - & - & - & - & - \\
9 & $\geq 100000$ & - & - & - & - & - \\
\hline
\end{tabular}


A2 Functions for calculating specific fuel consumptions depending on engine load

In the formulas, $f(x)$ is the specific fuel consumption in $\mathrm{g}(\mathrm{kWh})^{-1}$ and $0.25 \leq x \leq 1$ is the fractional load.

A2.1 Application E2: constant-speed main propulsion application (including diesel-electric drive or variable-pitch propeller installations)

$$
\begin{array}{rl}
\text { MCR }<2000 \mathrm{~kW} & f(x)=102 x^{2}-170 x+274 \\
2000 \geq \mathrm{MCR}<10000 \mathrm{~kW} & f(x)=102 x^{2}-171 x+260 \\
\mathrm{MCR} \geq 10000 \mathrm{~kW} & f(x)=40.1 x^{2}-53.2 x+191
\end{array}
$$

A2.2 Application E3: propeller-law-operated main and propeller-law-operated auxiliary engine application

$$
\begin{array}{r}
\text { MCR }<2000 \mathrm{~kW} f(x)=67.9 x^{2}-84.0 x+239 \\
2000 \mathrm{~kW} \geq \mathrm{MCR}<15000 \mathrm{~kW} f(x)=47.2 x^{2}-74.7 x+210 \\
\mathrm{MCR} \geq 15000 \mathrm{~kW} f(x)=46.1 x^{2}-69.2 x+201
\end{array}
$$

\section{A2.3 Application D2: constant-speed auxiliary engine} application

$f(x)=254.9 x^{-0.029}$

A3 Functions for calculating specific $\mathrm{NO}_{x}$ emissions depending on engine load

In the formulas, $f(x)$ is the specific $\mathrm{NO}_{x}$ emission in $\mathrm{g}(\mathrm{kWh})^{-1}$ and $0.25 \leq x \leq 1$ is the fractional load.

\section{A3.4 Application E3 TIER II}

$$
\begin{aligned}
\text { MCR }<2000 \mathrm{~kW} \quad f(x) & =-7.25 x^{3}+18.2 x^{2} \\
& -15.5 x+10.7 \\
2000 \mathrm{~kW} \geq \mathrm{MCR}<15000 \mathrm{~kW} \quad f(x) & =-14.8 x^{3} \\
& +27.7 x^{2}-19.0 x+17.2 \\
\mathrm{MCR} \geq 15000 \mathrm{~kW} \quad f(x) & =-32.0 x^{3}+57.2 x^{2} \\
& -31.6 x+18.6
\end{aligned}
$$

\section{A3.5 Application D2 TIER I \\ $f(x)=-0.005 x+14.7$}

\section{A3.6 Application D2 TIER II}

$$
f(x)=0.891 \log (x)+11.8
$$

\section{A3.1 Application E2 TIER I}

$$
\begin{array}{r}
\text { MCR }<2000 \mathrm{~kW} \quad f(x)=0.696 x^{2}-1.18 x+9.07 \\
2000 \mathrm{~kW} \geq \mathrm{MCR}<10000 \mathrm{~kW} \quad f(x)=-6.36 x^{3}+11.5 x^{2}-7.43 x+12.3 \\
\text { MCR } \geq 10000 \mathrm{~kW} \quad f(x)=-12.5 x^{2}+16.3 x+8.71
\end{array}
$$

\section{A3.2 Application E2 TIER II}

$$
\begin{array}{r}
\text { MCR }<2000 \mathrm{~kW} \quad f(x)=4.15 x^{2}-5.39 x+7.91 \\
2000 \mathrm{~kW} \geq \mathrm{MCR}<10000 \mathrm{~kW} \quad f(x)=-15.3 x^{3}+28.0 x^{2}-14.5 x+11.2 \\
\text { MCR } \geq 10000 \mathrm{~kW} \quad f(x)=-13.4 x^{2}+16.7 x+8.64
\end{array}
$$

\section{A3.3 Application E3 TIER I}

$$
\begin{aligned}
\text { MCR }<2000 \mathrm{~kW} \quad f(x) & =-12.1 x^{3}+27.3 x^{2} \\
& -20.8 x+12.5 \\
2000 \mathrm{~kW} \geq \mathrm{MCR}<15000 \mathrm{~kW} \quad f(x) & =-13.8 x^{3}+23.8 x^{2} \\
& -15.2 x+17.0 \\
\mathrm{MCR} \geq 15000 \mathrm{~kW} \quad f(x) & =-25.7 x^{3}+44.3 x^{2} \\
& -25.2 x+19.7
\end{aligned}
$$


Acknowledgements. This work was partly funded by the European Regional Development Fund (ERDF) within Interreg IVB projects Clean North Sea Shipping (CNSS) and CNSS Improved Dissemination and Impact (CNSS-IDI). The US EPA is gratefully acknowledged for the use of CMAQ; we thank Twan van Noije (KNMI) for providing TM5 model data. The emission inventory developed during the study is available as netCDF files on request.

The article processing charges for this open-access publication were covered by a Research

Centre of the Helmholtz Association.

Edited by: A. Richter

\section{References}

Bessagnet, B., Colette, A., Meleux, F., Rouil, L., Favez, O., Cuvelier, C., Thunis, P., Tsyro, S., Stern, R., Manders, A., Kranenburg, R., Aulinger, A., Bieser, J., Mircea, M., Briganti, G., Cappelletti, A., Calori, G., Finardi, S., Silibello, C., Ciarelli, G., Aksoyoglu, S., Prévot, A., Pay, M.-T., Baldasano, J., Garcia Vivanco, M., Garrido, J. L., Palomino, I., Martín, F., Pirovano, G., Roberts, P., Gonzalez, L., White, L., Menut, L., Dupont, J.-C., Carnevale, C., and Pederzoli, A.: The EURODELTA III exercise - Model evaluation with observations issued from the 2009 EMEP intensive period and standard measurements in Feb/Mar 2009, Tech. Rep. 1/2014, Cooperative programme for monitoring and evaluation of the long-range transmission of air pollutants in Europe EMEP, 2014.

Bieser, J., Aulinger, A., Matthias, V., Quante, M., and Builtjes, P.: SMOKE for Europe - adaptation, modification and evaluation of a comprehensive emission model for Europe, Geosci. Model Dev., 4, 47-68, doi:10.5194/gmd-4-47-2011, 2011.

Brandt, J., Silver, J. D., Christensen, J. H., Andersen, M. S., Bønløkke, J. H., Sigsgaard, T., Geels, C., Gross, A., Hansen, A. B., Hansen, K. M., Hedegaard, G. B., Kaas, E., and Frohn, L. M.: Assessment of past, present and future health-cost externalities of air pollution in Europe and the contribution from international ship traffic using the EVA model system, Atmos. Chem. Phys., 13, 7747-7764, doi:10.5194/acp-13-7747-2013, 2013.

Buhaug, Ø., Corbett, J., Endresen, Ø., Eyring, V., Faber, J., Hanayama, S., Lee, D., Lee, D., Lindstad, H., Markowska, A., Mjelde, A., Nelissen, D., Nilsen, J., Pålsson, C., Winebrake, J., Wu, W., and Yoshida, K.: Second IMO GHG Study, Tech. rep., International Maritime Organization (IMO), London, UK, 2009.

Byun, D. and Ching, J.: Science Algorithms of the EPA Models-3 Community Multiscale Air Quality Modeling System, Epa/600/r-99/030, US Environmental Protection Agency, Office of Research and Development, Washington DC, 1999.

Byun, D. and Schere, K.: Review of the Governing Equations, Computational Algorithms, and Other Components of the Models-3 Community Multiscale Air Quality (CMAQ) Modeling System, Appl. Mech. Rev., 59, 51-77, 2006.

Denier van der Gon, H. and Hulskotte, J.: Methodologies for estimating shipping emissions in the Netherlands, BOP reports 500099012, Netherlands Environmental Assessment Agency, (PBL), Netherlands Environmental Assessment Agency, (PBL) PO BOX 303, 3720 AH Bilthoven, The Netherlands, this is a publication of the Netherlands Research Program on Particulate Matter, 2010.

Dentener, F., Kinne, S., Bond, T., Boucher, O., Cofala, J., Generoso, S., Ginoux, P., Gong, S., Hoelzemann, J. J., Ito, A., Marelli, L., Penner, J. E., Putaud, J.-P., Textor, C., Schulz, M., van der Werf, G. R., and Wilson, J.: Emissions of primary aerosol and precursor gases in the years 2000 and 1750 prescribed data-sets for AeroCom, Atmos. Chem. Phys., 6, 4321-4344, doi:10.5194/acp-64321-2006, 2006.

EEA: EMEP/EEA air pollutant emission inventory guidebook 2013, Tech. Rep. 12, European Environment Agency, doi:10.2800/92722, 2013.

EMEP: The European Monitoring and Evaluation Programme, website, available at: http://www.emep.int/, last access: January 2015.

EMEP/CEIP: Present state of emission data, website, available at: http://www.ceip.at/webdab_emepdatabase/reported_ emissiondata, last access: June 2014.

EMEP/CEIP: Present state of emission data, website, available at: http://www.ceip.at/webdab_emepdatabase/reported_ emissiondata, last access: November 2015.

Eyring, V., Kohler, H. W., Lauer, A., and Lemper, B.: Emissions from international shipping: 2. Impact of future technologies on scenarios until 2050, J. Geophys. Res.-Atmos., 110, D17306, doi:10.1029/2004JD005620, 2005a.

Eyring, V., Kohler, H. W., van Aardenne, J., and Lauer, A.: Emissions from international shipping: 1 . The last 50 years, J. Geophys. Res.-Atmos., 110, D17305, doi:10.1029/2004JD005619, 2005 b.

Hammingh, P., Holland, M. R., Geilenkirchen, G. P., Jonson, J. E., and Maas, R. J. M.: Assessment of the environmental impacts and health benefits of a nitrogen emission control area in the North Sea, Tech. rep., PBL Netherlands Environmental Assessment Agency, 2012.

Huijnen, V., Williams, J., van Weele, M., van Noije, T., Krol, M., Dentener, F., Segers, A., Houweling, S., Peters, W., de Laat, J., Boersma, F., Bergamaschi, P., van Velthoven, P., Le Sager, P., Eskes, H., Alkemade, F., Scheele, R., Nédélec, P., and Pätz, H.-W.: The global chemistry transport model TM5: description and evaluation of the tropospheric chemistry version 3.0, Geosci. Model Dev., 3, 445-473, doi:10.5194/gmd-3-445-2010, 2010.

IMO: Amendments to the Annex of the Protocol of 1997 to Amend the International Convention for the Prevention of Pollution from Ships, 1973, as Modified by the Protocol of 1978 Relating thereto (MARPOL Annex VI), available at: http://www.imo.org/includes/blastDataOnly.asp/ data_id\%3D23760/176(58).pdf (last access: October 2015), 2008.

Jalkanen, J.-P., Johansson, L., Kukkonen, J., Brink, A., Kalli, J., and Stipa, T.: Extension of an assessment model of ship traffic exhaust emissions for particulate matter and carbon monoxide, Atmos. Chem. Phys., 12, 2641-2659, doi:10.5194/acp-12-26412012, 2012.

Johansson, L., Jalkanen, J.-P., Kalli, J., and Kukkonen, J.: The evolution of shipping emissions and the costs of regulation changes in the northern EU area, Atmos. Chem. Phys., 13, 11375-11389, doi:10.5194/acp-13-11375-2013, 2013. 
Jonson, J. E., Gauss, M., Jalkanen, J. P., Nyíri, A., and Johansson, L.: EMEP model calculations of the effects of ship emissions in the Baltic Sea and the North Sea, Clean Shipping Currents, 2014.

Kurok, C.: Partikelminderung durch Schwefelgrenzwerte, Schiff \& Hafen, 2008.

Lack, D. A. and Corbett, J. J.: Black carbon from ships: a review of the effects of ship speed, fuel quality and exhaust gas scrubbing, Atmos. Chem. Phys., 12, 3985-4000, doi:10.5194/acp-12-39852012, 2012.

Lauer, A., Eyring, V., Corbett, J. J., Wang, C. F., and Winebrake, J. J.: Assessment of Near-Future Policy Instruments for Oceangoing Shipping: Impact on Atmospheric Aerosol Burdens and the Earth's Radiation Budget, Environ. Sci. Technol., 43, 55925598, 2009.

MARIN: MARIN's emissions inventory for North Sea shipping 2009: validation against Ente's and extension with port emissions., Tech. Rep. 25300-1-MSCN-rev.2, Maritime Research Institute Netherlands, Wageningen, the Netherlands, 2011.

Matthias, V., Bewersdorff, I., Aulinger, A., and Quante, M.: The contribution of ship emissions to air pollution in the North Sea regions, Environ. Pollut., 158, 2241-2250, doi:10.1016/j.envpol.2010.02.013, 2010.

Matthias, V., Aulinger, A., Backes, A., Bieser, J., Geyer, B., Quante, M., and Zeretzke, M.: The impact of shipping emissions on air pollution in the greater North Sea region - Part 2: Scenarios for 2030, Atmos. Chem. Phys., 16, 759-776, doi:10.5194/acp-16759-2016, 2016.

Mollenhauer, K. and Tschöke, H.: Handbuch Dieselmotoren, Springer, 2007.
Project, Clean North Sea Shipping (CNSS): Final Report - Key findings and Recommendations, pdf, available at: http://www. cnss.no (last access July 2015), 2014.

Rockel, B., Will, A., and Hense, A.: The Regional Climate Model COSMO-CLM(CCLM), Meteorol. Z., 17, 347-348, 2008.

VDI: Measurement of soot (Immission) Chemical Analysis of Elemental Carbon by Extraktion and Therman Desorption of Organic Carbon, VDI-Richtlinien 2465 Part 1, Verein Deutscher Ingenieure, 1996.

VDI: Measurement of soot (Ambient Air) Thermographical determination of elemental carbon after thermal desorption of organic carbon, VDI-Richtlinien 2465 Part 2, Verein Deutscher Ingenieure, 1999.

Vinken, G. C. M., Boersma, K. F., van Donkelaar, A., and Zhang, L.: Constraints on ship $\mathrm{NO}_{x}$ emissions in Europe using GEOSChem and OMI satellite $\mathrm{NO}_{2}$ observations, Atmos. Chem. Phys., 14, 1353-1369, doi:10.5194/acp-14-1353-2014, 2014.

Whall, C., Cooper, D., Archer, K., Twigger, L., Thurston, N., Ockwell, D., McIntyre, A., and Ritchie, A.: Quantification of emissions from ships associated with ship movements between ports in the European Community, Tech. rep., ENTEC UK Limited, Windsor House Gadbrook Business Center Gadbrook Road Norwitch Cheshire CW9 71TN England, 2002.

Zeretzke, M.: Entwicklung eines Modells zur Quantifizierung von Luftschadstoffen, die durch Schiffsdieselmotoren auf See emittiert werden, Master's thesis, Technische Universität HamburgHarburg, 2013. 